\title{
Textile cell-free scaffolds for in situ tissue engineering applications
}

\author{
Dilbar Aibibu $^{1} \cdot$ Martin Hild $^{1} \cdot$ Michael Wöltje $^{1} \cdot$ Chokri Cherif $^{1}$
}

Received: 23 November 2015 / Accepted: 20 December 2015/Published online: 22 January 2016

(C) The Author(s) 2016. This article is published with open access at Springerlink.com

\begin{abstract}
In this article, the benefits offered by microfibrous scaffold architectures fabricated by textile manufacturing techniques are discussed: How can established and novel fiber-processing techniques be exploited in order to generate templates matching the demands of the target cell niche? The problems related to the development of biomaterial fibers (especially from nature-derived materials) ready for textile manufacturing are addressed. Attention is also paid on how biological cues may be incorporated into micro-fibrous scaffold architectures by hybrid manufacturing approaches (e.g. nanofiber or hydrogel functionalization). After a critical review of exemplary recent research works on cell-free fiber based scaffolds for in situ TE, including clinical studies, we conclude that in order to make use of the whole range of favors which may be provided by engineered fibrous scaffold systems, there are four main issues which need to be addressed: (1) Logical combination of manufacturing techniques and materials. (2) Biomaterial fiber development. (3) Adaption of textile manufacturing techniques to the demands of scaffolds for regenerative medicine. (4) Incorporation of biological cues (e.g. stem cell homing factors).
\end{abstract}

Dilbar Aibibu

dilibaier.aibibu@tu-dresden.de

1 Technische Universität Dresden, Fakultät Maschinenwesen, Institut für Textilmaschinen und Textile Hochleistungswerkstofftechnik, 01062 Dresden, Germany

\section{Introduction}

The classical tissue engineering (TE) approach (in vitro expansion of cells seeded on scaffolds and subsequent implantation) has been facing various critical obstacles concerning the translation to the bedside, namely seedingtime, laborious effort and cost [1-3]. Hence, in recent years in situ TE has gained increasing attention [4-8]. In this more straight-forward approach, the body's own biologic resources and reparative capability are utilized by implanting a cell-free engineered biomaterial (scaffold) into the site of injury, where host stem cells or tissue specific progenitor cells are recruited [2]. In situ TE approaches have been investigated for various possible applications such as vascular grafts [9], nerve [10] and hard tissue regeneration [11].

In recent years the general understanding of the requirements imposed on scaffolds for TE applications has changed towards templates which replicate the target cell niche in terms of their structural architecture and which are capable of adapting to a changing microenvironment, thus providing optimal conditions for tissue-ingrowth, nutrient, gas and biomolecule transport and vascularization [12, 13]. The scaffold architecture should be dictated by the requirements of the target cell niche (Fig. 1). To generate scaffolds with properties tailored to the targeted application, numerous manufacturing methods have been employed. Those comprise solvent casting [14-16], gas foaming [17-19], phase separation [20, 21], emulsion freeze drying [22-24], additive manufacturing (AM) techniques [25-27], electrospinning [28, 29] and other fiber formation techniques [30, 31].

The versatility of textile technology allows for the fabrication of 3D spatial structures with tunable properties in the micro- and macro range [32, 33]. In the past decades, textile manufacturing techniques have been used in a wide range of 
Fig. 1 Scaffold development approach based on the requirement of the target cell niche

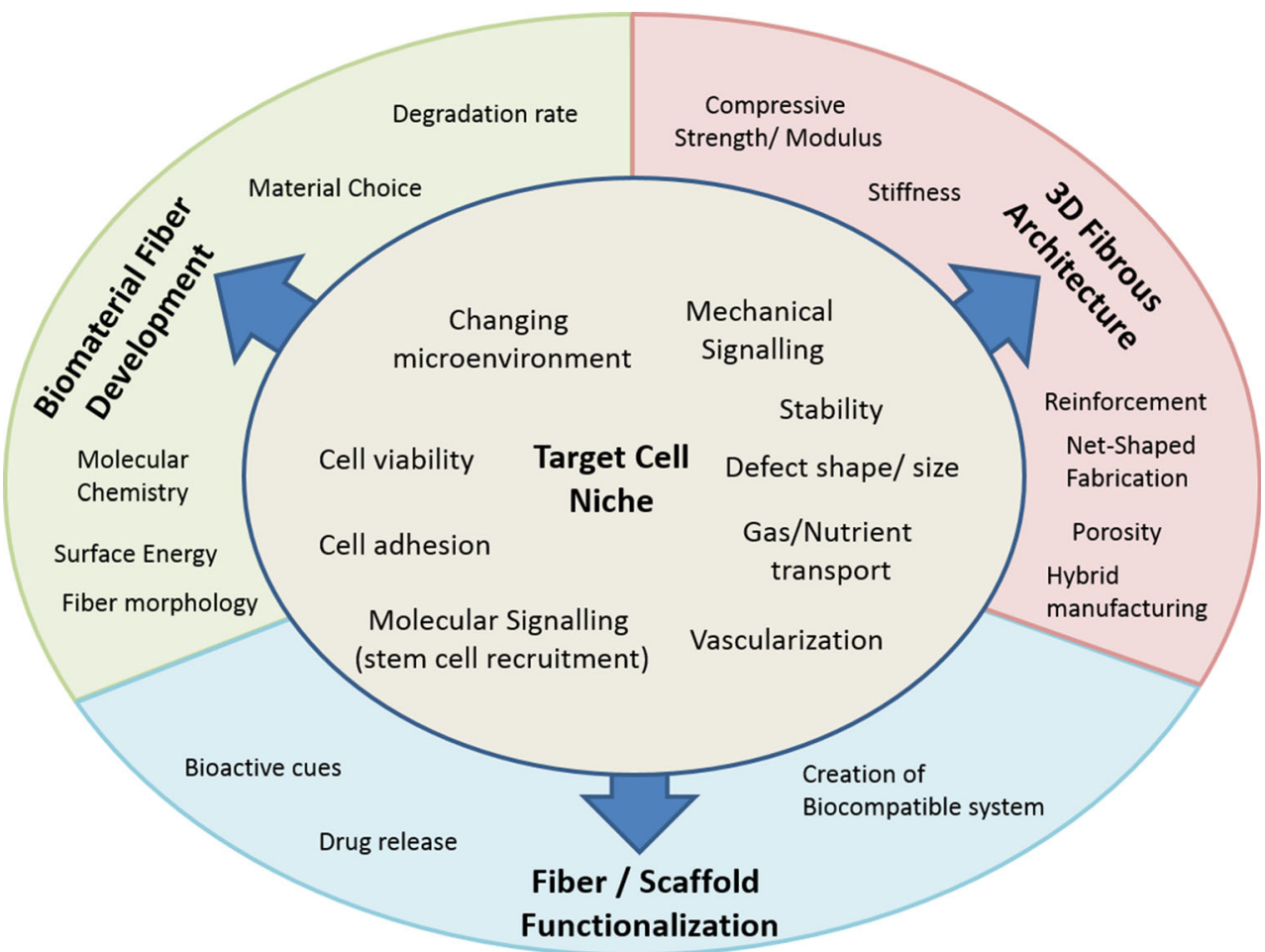

engineering applications such as fiber reinforced composites [33], construction textiles [34], filtration [35], medical textiles [36] etc. Fiber based techniques including electrospinning have been successfully used for the manufacturing of 3D cell laden scaffolds for classical in vitro and in vivo TE approaches, which are reviewed elsewhere [28, 30]. Through suitable combinations of material, fiber type and manufacturing technique, fiber-based scaffolds can be engineered to obtain properties similar to native tissue and to match critical scaffold criteria [37]. The mechanical properties can be adjusted according to the desired properties of native tissue [38-40]. Besides close structural resemblance of the scaffold to native host tissue, the success of in situ TE approaches strongly relies on the scaffolds capability to recruit host stem cells or tissue specific progenitor cells [2]. Therefore, information-rich scaffolding systems with incorporated "cell homing" or "recruiting" factors are needed [7, 41]. Nanofiber based scaffolds have been reviewed in detail elsewhere [42, 43]. Hence, in this review nanofibers are considered in terms of a major technique for scaffold functionalization and not as structure defining component.

In this article, the benefits offered by micro-fibrous scaffold architectures fabricated by textile manufacturing techniques are discussed:

How can established and novel fiber-processing techniques be exploited in order to generate templates matching the demands of the target cell niche?
Which are the problems related to the development of biomaterial fibers ready for textile manufacturing?

How may biological cues be incorporated into microfibrous scaffold architectures?

After a critical review of exemplarily selected recent studies on cell-free fiber based scaffolds for in situ TE, including clinical trials, the findings of this article are concluded in order assess the potential and limitations of cell-free fiber based scaffolds.

\section{Benefits of engineered fibrous scaffold architectures}

Textile technology offers various manufacturing methods to fabricate scaffolds with tailored properties. For centuries, textile manufacturing techniques have been used in the traditional branches of textile industry [44]. Detailed descriptions of the principles of knitting, weaving, braiding and non-woven fabrication as well as their respective characteristics are given elsewhere [32, 33, 45]. This section describes the favors principally given by fiber and textile technology to design scaffolds with adjustable properties matching the target cell niche (Fig. 2). At the same time, limitations and shortcomings of the current state of the art in fibrous scaffold engineering are discussed. 


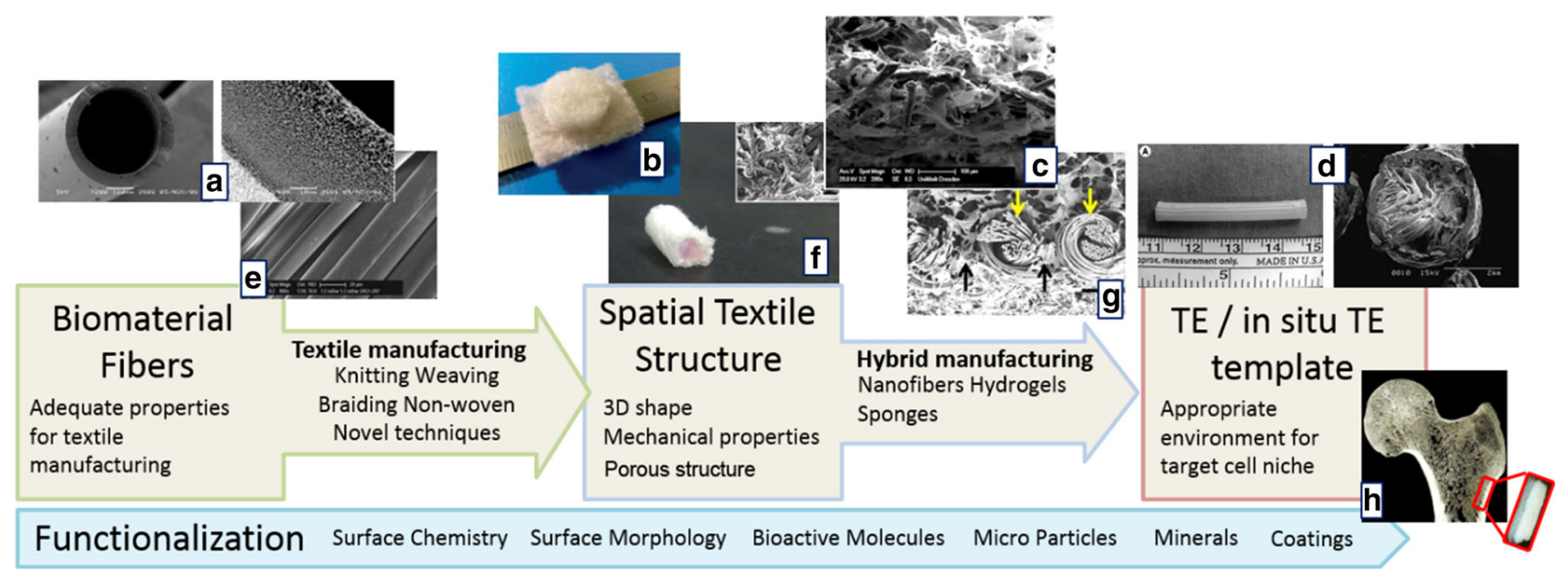

Fig. 2 Engineering process of fibrous architectures as templates for TE/in situ TE applications. Image source: a [46], b [47], c [48], d [49], e [50], f [51], $\mathbf{g}$ courtesy of TU Dresden

\subsection{Textiles: three-dimensional spatial structures with hierarchical porous properties}

There are two major groups of fibrous scaffolds for TE and in situ TE applications: Electrospun nanofibrous meshes and microfibrous textiles. Nanofibrous scaffolds have gained increasing attention in the past decade [42]. They are popular due to their high surface- to volume ration, the beneficial scale-dimensions for cell adhesion and the diversity of biomaterials which may be processed [28]. However, nanofibrous scaffolds are restricted to flat, "twodimensional" pads, tubed membranes or mechanically instable spatial structures in the most cases [42]. The benefit of fibrous engineered architectures which is most often exploited is their reinforcing function $[52,53]$. The mechanical properties are identified as a crucial factor for TE scaffolds [49, 54], remarkable coherences between mechanical stability and cell attachment were found [55, 56].

Engineered fibrous constructs are mostly incorporated into scaffolds as either flat textile fabrics or tubular structures made by rolling of flat fabrics or directly produced by braiding or knitting techniques. An issue which is less addressed in studies using engineered fibrous scaffolds is the call for scaffolds with defined pore size and porosity and with 3D shapes which match specific anatomies. To match these requirements, additive manufacturing (AM) techniques have gained increasing attention [25, 57]. The benefits of AM techniques in scaffold manufacturing are underlined in various studies $[25,57]$. Besides this, textile manufacturing methods may also be employed for the fabrication of mechanically stable, three-dimensional spatial structures with hierarchical porous properties. With the available conventional manufacturing methods (e.g. flat- knitting, 3D weaving, braiding), net-shaped geometries may be realized [33]. The pore structure of textile fabrics can be adjusted by varying the manufacturing parameters [58]. To learn why there are only little studies using complexly custom-shaped fibrous scaffolds one has to look at the manufacturing methods and the research fields that must be involved.

One main impediment is that industrial textile machines commonly are in scale dimensions that are inappropriate for the fabrication of scaffolds. Furthermore, textile manufacturing of complex 3D-structures requires expert knowledge from textile engineering professionals. There are several examples in which stronger interdisciplinary collaboration could have helped to improve the architecture of the fibrous scaffolds [48, 59-61], thus further improving the positive results. In order to being able to exploit the whole bandwidth of benefits offered by engineered fibrous scaffolds, the technique which suits best for the desired application needs to be identified among the variety of available techniques. For instance, circular knitting could be considered for the fabrication of tubular samples rather than wrapping and suturing knitted flat patches [48, 60]. Manufacturing techniques may also have to be adapted to match the demands of scaffold-fabrication. The trend towards multi-material "hybrid" scaffolds with macro- and nano-scaled elements which most closely mimic the host tissue niche [12, 62] demands flexible manufacturing methods which allow the combination of the fibrous architecture with other materials (e.g. nano-fibers, hydrogels). A manufacturing technique by which fibrous scaffolds are fabricated similar to AM techniques was developed by Hild et al. [47]. Another feature which may be addressed with the help of textile manufactur ing methods is the incorporation of nanofibers into $3 \mathrm{D}$ 
stable scaffolds $[47,63,64]$. Such a combination of microand nano-scaled elements can be employed to make use of the favorable properties of nanofibers in a mechanically stable 3D spatial environment [26] and to create hierarchical porous structures which are important for scaffold vascularization [65].

\subsection{Biomaterial fiber development for use in engineered fibrous scaffolds}

Theoretically most materials can be processed into fibers by different fiber formation techniques like melt- wet- or dry-spinning [66, 67], electrospinning [68] including nanofiber yarns [69, 70], bio-spinning [71], interfacial complexation [72] and microfluidic techniques [73]. However, fibers which may be used in textile manufacturing processes must meet certain criteria, namely mechanical strength, elasticity, fiber diameter, fiber length, yarn count [45]. To this date, these criteria basically restrict the fiber formation techniques which are suitable for subsequent textile manufacturing methods to melt- wet- and bio-spinning. Due to the above-mentioned reasons, scaffolds made by textile manufacturing techniques are in most cases made of synthetic melt- or wet-spun polymers (e.g. PLA, PGA, PLLA, PLGA, PCL) [74]. To make use of other promising natural or nature-derived biomaterials for the fabrication of stable 3D spatial fibrous scaffolds, intensified fiber development research is necessary. Conventional fiber spinning techniques like wet or melt spinning may generally be used for biomaterial fiber fabrication. However, they often come along with harsh processing conditions (high temperatures, strong/toxic solvents), which could lead to denaturation of the biomaterial during fiber formation or to the presence of toxic substances in the fabricated fibers. For the production of biomaterial fibers, novel approaches have to be followed [75] and existing spinning techniques have to be adapted in order to preserve the microstructure of the biomaterials (i.e. benign solvents, moderate process temperatures). In this section, studies that aim at processing promising biomaterials (collagen, chitosan, regenerated silk, recombinant proteins) into fibers suitable for textile manufacturing techniques are presented (Fig. 3). Detailed descriptions of the respective biomaterial properties can be found elsewhere [76-79].

\subsubsection{Collagen fibers}

Collagen, the major component of native ECM, befits an outstanding role in TE and in situ TE. The beneficial properties of collagen (as explained elsewhere [76]) have been exploited in numerous studies in all sub-branches of TE $[81,82]$. Since the first study on reconstituted collagen fibers by extrusion from acidified collagen gels different routes have been followed in order to develop aligned fibers which possess sufficient mechanical strength for their intended use and replicate the micro and nano-structural composition of native collagen [83]. In recent years, significant progress towards these goals has been made using extrusion and electrochemical alignment techniques, respectively.

Wet-spinning of collagen fibers can be realized by extruding acidified collagen gels into a pH-neutral buffer, where in vitro fibrillogenesis takes place [84]. Based on this approach, research has been conducted in order to improve the mechanical strength [85], increase production rates [86], adjust the fiber properties by using different coagents, solution concentrations and collagen sources [8789] and examine fiber crosslinking [90]. Fiber-diameters of 10-2000 $\mu \mathrm{m}$ can be realized [83]. Although D-banded collagen fibers can be verified [91], it remains unclear whether native-type collagen without substantial proportions of gelatin (denaturalized collagen) can be produced by extruding acidified collagen [83]. Furthermore, the usage of polyethylene glycol (PEG) in the fiber formation buffer increases the wet fiber strength but results in nonpure collagen fibers [92]. In addition, extruded collagenfibers are mechanically weak. Crosslinking may elevate the ultimate strength of to an adequate level (10.5 MPa), but at the same time negatively influences the cell-seeding properties [93-96]. Another challenge lies in the fabrication of multi-filament yarns. While most studies describe the fabrication of single fibers, there is little and unsatisfying work on the production of multi-filament collagen yarns that may be used for textile manufacturing [97]. The limitations described above render extruded collagen fibers impractical for textile manufacturing methods.

By describing an electrochemical alignment technique, Akkus et al. published pioneer work on engineered collagen fibers. The principle of axial alignment of dialyzed collagen along the isoelectric point and subsequent fibrillogenesis in phosphate buffered saline (PBS) at $37{ }^{\circ} \mathrm{C}$ and genipin crosslinking was first described by Cheng et al. [75]. By adjusting the genipin-crosslinking protocol, the mechanical strength of the electronically aligned collagen (ELAC) could be elevated to $109 \mathrm{MPa}$, which is in the range of native tendon [98]. Younesi et al. developed a rotating electrode device for the continuous fabrication of ELAC fibers (Fig. 3a-e) [80]. However, the production speed remains unclear. They twisted three single fibers (ultimate tensile strength $20-50 \mathrm{MPa}, 0.1-0.15 \mathrm{~mm}$ fiber diameter) to a collagen thread (ultimate tensile strength $65 \mathrm{MPa}$ ) and used a hand weaving technique to produce a 3D bio-textile made of pure collagen fibers. hMSC's proliferated and distributed throughout the highly porous scaffold underwent tenogenic differentiation even though 


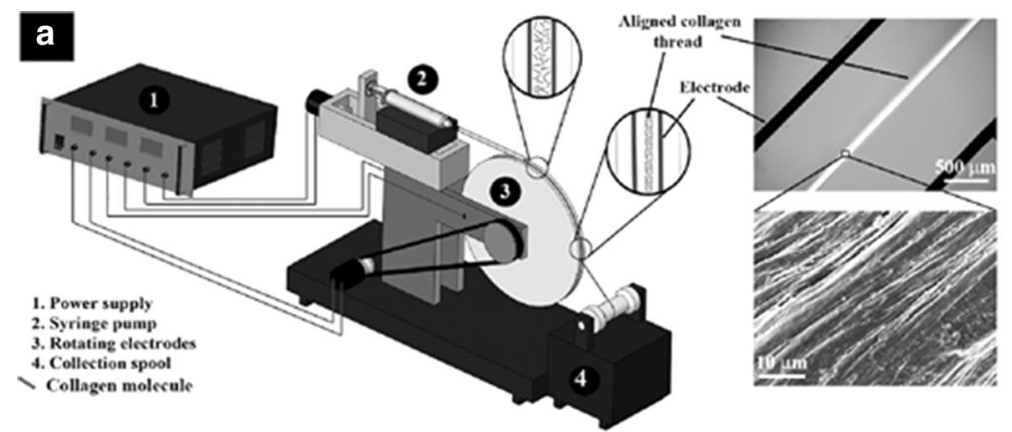

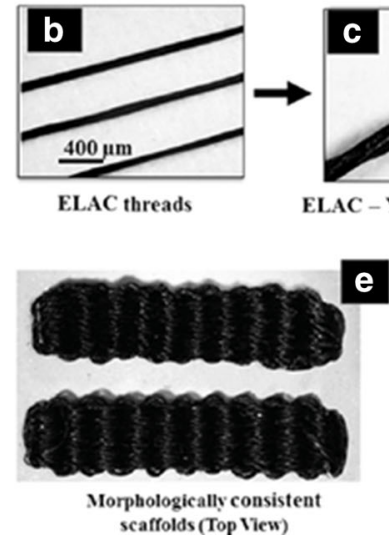

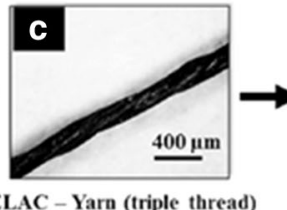

e

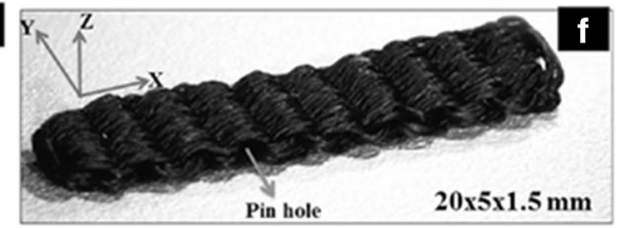

Woven ELAC Scaffold
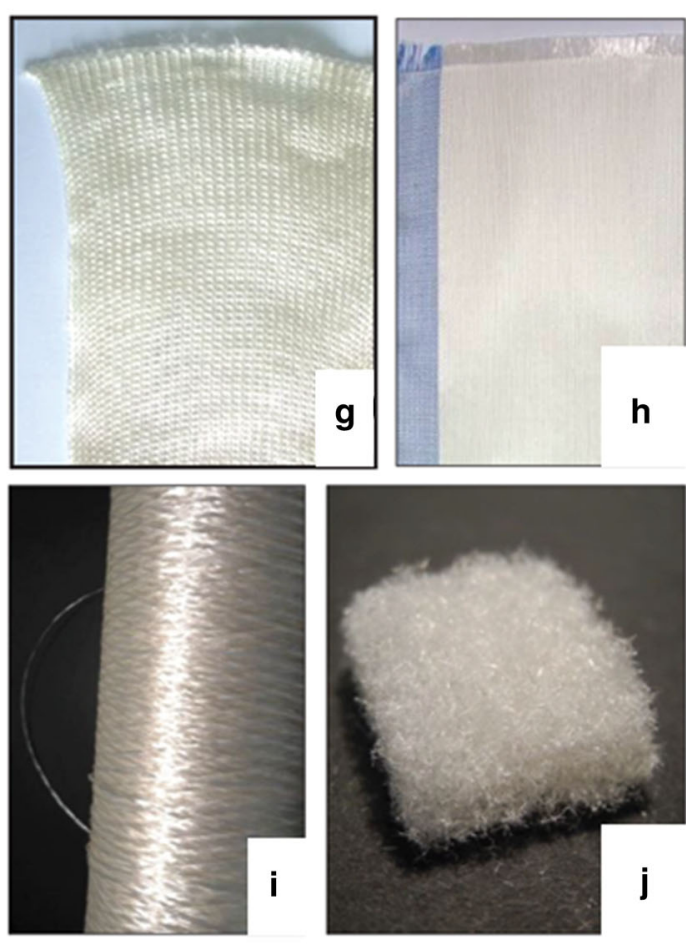

Fig. 3 Examples for biomedical fiber development. Schematic of device for the fabrication of endless collagen filament by electrochemical alignment (a), electrochemically aligned collagen (ELAC)

no growth factors were added [80]. However, the authors state that thinner filaments could be beneficial for cell alignment. Thinner filaments would be also useful for textile fabrication processes. If in vivo examinations of this novel collagen-fiber material prove successful, electrochemical alignment could be a breakthrough technique for the fabrication of pure collagen fibers.

Besides the promising developments in collagen fiber development, there are some unsolved problems. For example, there is a controversy about the correct crosslinking procedure or whether collagen should be crosslinked at all [99]. Furthermore, current studies describe collagen fiber production on the laboratory scale in which single fibers or fiber bundles comprising up to six fibers are produced [94]. From the materials' engineering point of view, the next steps should include up-scaling of the fiber fabrication process with the goal to produce multifilament yarns and processing the collagen yarns on textile machinery. Another critical issue remains the verification of the ultrastructural features of collagen in fibers labeled as "collagen fiber". There are studies on "collagen" fiber scaffolds that lack the verification of collagen and in which the source of the collagen fibers remains unclear [100, 101]. fibers (b), twisted thread (c) and pin-woven scaffold made of ELAC fibers (d, e); Chitosan fibers (f), non-woven (g), knitted (h) and woven (i). a-e from Ref. [80], f-i from [51]

\subsubsection{Chitosan fibers}

Due to its favorable properties (e.g. abundant availability, osteoactivity, promotes wound healing, anti-bacterial effects) Chitosan (CS), a partially deacetylated derivative of Chitin, has been widely used in applications for regenerative medicine $[102,103]$. Chitosan fibers may be produced by electrospinning [104], microfluidic spinning [105] or wet spinning techniques [51, 106-108].

$\mathrm{Li}$ and colleagues reported the fabrication of CS fibers from glycine chloride ([Gly]Cl) ionic liquid spinning dopes. 5-7 wt $\%$. CS dissolved in in $4 \mathrm{wt} \%$ aqueous acetic or $[\mathrm{Gly}] \mathrm{Cl}$ solutions was spun with a spinneret $(20$ holes, $80 \mu \mathrm{m} \emptyset)$. The filaments were coagulated in a dilute $\mathrm{Na} 2 \mathrm{SO} 4 / \mathrm{C} 2 \mathrm{H} 5 \mathrm{OH}$ bath. Adequate mechanical properties (maximum breaking tenacity: $3.77 \mathrm{cN} / \mathrm{dtex}$, maximum initial modulus: $2.3 \mathrm{cN} / \mathrm{dtex}$ ) were registered [109]. Yan an co-workers used chitin nanocrystal (ChiNC) as nanofiller to reinforce CS fibers spun according to 109, leading to increased mechanical properties [110]. Chitosan microfibers reinforced by chitin nanofibrils were studied by Yudin et al. [111]. The incorporation of $0.1-0.3 \mathrm{wt} \%$ of chitin nanofibrils into chitosan matrix led to an increase in strength and Young modulus. 
Toskas and colleagues successfully developed an industrial-scale process to generate pure chitosan multifibers (Fig. 3f-i) [51]. They dissolved up to $8.5 \mathrm{wt} \%$. CS in aqueous acetic solutions. The CS solution was pressed through a spinneret (150-600 holes, 20-120 $\mu \mathrm{m} \varnothing)$ and led through a coagulation bath composed of $\mathrm{NaOH} / \mathrm{EtOH}$. The fiber diameter could be adjusted from 20.7 to $36.0 \mu \mathrm{m}$. Tensile strength of $15.9 \mathrm{cN} /$ tex was achieved. Woven and knitted fabrics with adequate mechanical properties could be manufactured [51]. Textile scaffolds made of these CS fibers were tested in vitro, yielding promising results for further use in TE applications [47, 112]. Chitosan-based hyaluronic acid fibers were developed by Yamane et al [113]. They used spinning dopes of $3.5 \% \mathrm{CS}$ in $2 \%$ aqueous acetic solutions, a spinneret with 50 holes and $0.1 \mathrm{~mm} \varnothing$ and a calcium coagulant bath. Hyaluronic acid (HA) was added in an aqueous methanol solution coagulation bath. CS-HA fibers showed higher tensile strengths $\left(168.2 \pm 7.0 \mathrm{~N} / \mathrm{mm}^{2}\right)$ than CS only fibers $(87.4 \pm 2.0 \mathrm{~N} /$ $\mathrm{mm}^{2}$ ) [113]. This fiber-type was used for the fabrication of 3D woven scaffolds [114]. Implantation into cartilage defects in rabbits led to regeneration of hyaline-like cartilage [108, 115].

Similar to collagen fibers, the successful works on chitosan fiber development call for intensified studies about their in vivo behavior in order to utilizing fibrous chitosan structures as scaffolds for TE and in situ TE applications.

\subsubsection{Regenerated silk fibers}

Silk fibroin-based scaffolds have been used in various TE and in situ TE applications [116]. Although silk fibers directly harvested from the spinning gland of spiders (Ampullate/Dragline fibroins) or silkworms (Bombyx mori) provide excellent properties (e.g. mechanical stability, beneficial cellular reactions, biodegradability) they also have shortcomings in terms of material inhomogeneity, varying material properties and the low availability of spider silk [79, 117]. To elude these problems which come along with the use of biospun fibers, extensive research has been put on the development of wet-spinning techniques for regenerated silk fibers.

The fabrication of regenerated silk fibroin (RSF) fibers is a challenging subject. Critical factors are the molecular weight and concentration of silk fibroin [118], the solvent system [119, 120], the solidification rate of the spinning dope [121], the post-drawing ration [122] and the preservation of flexibility in the dry state [123]. Conductive RSF may be developed by the incorporation of multiwalled carbon nanotubes (MWNTs) [124]. Their biocompatibility may be improved by adding calcium chloride to the spinning solution [125]. Due to the limited availability from natural sources, recombinant production is especially attractive for spider silk proteins [117]. Synthetic recombinant Major Ampullate spider silk fibers were produced by self-assembly [126-128] or wet-spinning [129-131]. There are studies about the recombinant production and subsequent fiber-spinning of other proteins than silk fibroins, e.g. silk-elastin like proteins [132], Amyloid Protein [133], honeybee silk [134] or Keratin [135]. Those materials could be used to create novel fibers with favorable properties for their use in regenerative medicine. However, these attempts had limited success regarding the mechanical properties of the fibers.

\subsection{Fiber and scaffold functionalization for the incorporation of stem cell homing factors}

Fiber science provides useful techniques for the incorporation of functional substances into scaffolds. Much research has been conducted on drug-loading and release of fibers [136-138] and fiber based scaffolds [139]. The use of hollow fibers with interconnected micro-pores through the fiber wall has been studied for TE applications [140]. Fiber surfaces can be functionalized with a diversity of nano- and micro-particles in order to improve certain scaffold properties [141, 142]. The available techniques for fiber functionalization and drug-release could also be used for the incorporation and sustained release of biological cues such as stem cell homing factors into fibrous architectures. The possible mechanisms for the loading of fibers with biological cues are discussed in detail elsewhere [62].

Despite the manifold possibilities to functionalize fibers, the only aqueous coatings [143-145] and gels [48, 63, 146] have been used for the incorporation of biological cues into textile scaffolds. Effective stem-cell recruitment by coating a technique was achieved by Erggelet et al. [144]. They prepared cell-free scaffolds by cutting commercially available non-wovens of polyglycolic acid (PGA) into the desired shape and soaking them with hyaluronic acid. Directly prior to implantation into full-thickness articulate cartilage defects of merino sheep, the scaffolds were soaked in autologous sheep serum which served as chemoattractant. Three months after implantation, the formation of a cell-rich repair tissue of cartilaginous appearance was observed. The authors conclude that the scaffold allows the in situ recruitment of mesenchymal stem cells (MSCs) by serum as a chemo-attractant and subsequent guidance of the progenitor cells towards formation of cartilage repair tissue [144]. A similar scaffold system (PGA non-woven soaked with hyaluronic acid and allogenic serum) was used for the regeneration of the intervertebral disc in rabbits [145]. In another study, coating of knitted polyester vascular grafts with fibronectin (FN) and the stem cell homing factor SDF-1 alpha led to positive results [143]. As these findings suggest, coating is a rather simple technique that 
can easily be used directly prior to implantation, but it comes along with the limitation that the biological cue is only present on the fiber-surface, which impedes time-dependent release kinematics.

Hydrogels may be used for local release of biological cues. For the regeneration of anterior cruciate ligament (ACL) defects in rabbits, Kimura et al. incorporated braided poly-L-lactic acid (PLLA) scaffolds with a basic fibroblast growth factor (bFGF) loaded hydrogel in the region of bone and with a collagen wrapping in the joint cavity [146]. The authors observed significant bone regeneration around the scaffold in the bone tunnel, which could have been supported by enhanced cell migration due to local bFGF release (Fig. 4b) [146]. Shen and co-workers developed a bioactive scaffold made of knitted silk and a collagen sponge with incorporated cell homing factor SDF1 alpha [48]. This scaffold for Achilles tendon regeneration led to a reduction of inflammatory cells, SDF-1 alpha caused increased selective recruitment of fibroblast-like cells. Four weeks post-surgery, enhanced local endogenous SDF-1 alpha and extracellular matrix (ECM) production was registered [48].

The described findings show that the incorporation of biological cues into textile scaffolds for in situ TE can lead to favorable outcomes. With the help of available fiber functionalization techniques, a broader range of substances could be incorporated and programmable release kinetics of biological cues from degradable fibers could be realized.

\section{Textile cell-free scaffolds used for in situ tissue engineering}

This section gives an overview on recent studies in which fibrous scaffolds are used for in situ TE applications. A focus is put on the textile substrates and their incorporation into the scaffold system. Only the most important features of the different manufacturing techniques are discussed in order to point out their benefits for their use as cell-free scaffolds.

\subsection{Knitted scaffolds}

With knitting technology, three-dimensionally net-shaped geometries are easily realizable [148-150]. Due to their highly ordered loop-structure [151], knitted fabrics are generally more elastic than woven or braided structures. Using different knitting techniques and patterns (e.g. jersey, interlock), the mechanical [152] and porous [153] properties of knitted scaffolds may be tailored to suit the specific demands of most sub-areas of regenerative medicine [37]. This section describes successful studies using knitted cell-free scaffolds, undermining the versatility and suitability of knitting technology for the fabrication of cellfree scaffolds.

A scaffold design based on the requirements of the target cell niche, by logically combining different manufacturing techniques and materials, was realized by
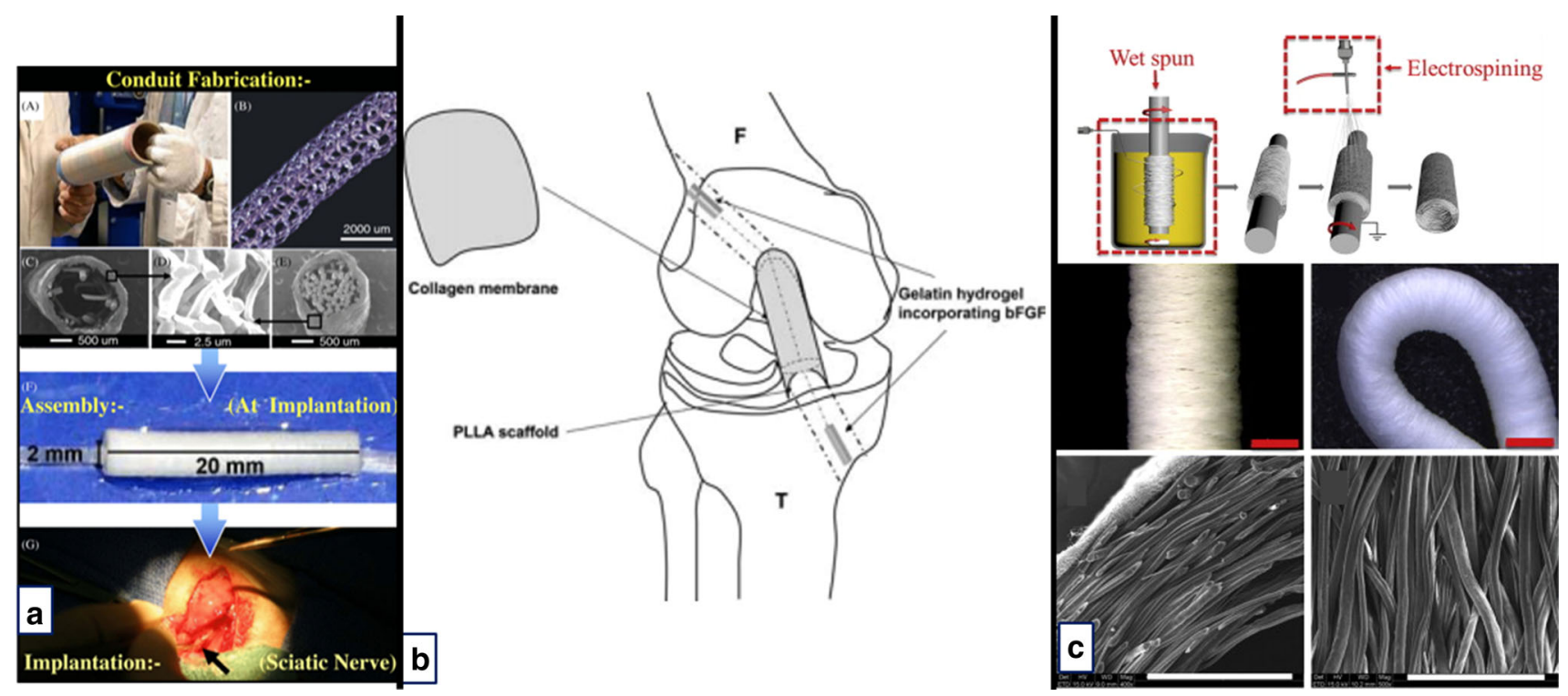

Fig. 4 a Engineering process of multimodal nerve conduit based on a tubular knit coated with electrospun nanofibers and incorporated with aligned guidance fibers [63]. b Scaffold design based on the requirements of different implantation sites: Hydrogels incorporating
bFGF localized to the bone tunnels, collagen wrapping in the joint cavity [146]. c Hybrid vascular scaffold made of wet-spun microfibers and electrospun nanofibers; manufacturing scheme, photographs and SEM images of scaffolds [64, 147] 
Quigley et al. [63]. They knitted a sheath from PLA monofilaments $(90-100 \mu \mathrm{m} \varnothing)$ which was coated with electrospun PLA nanofibers to obtain controlled pore sizes favorable for nerve conduits $<2 \mu \mathrm{m}$ [154]. This sheath was filled with two types of aligned (PLGA) guidance fibers (30-40 $\mu \mathrm{m} \varnothing)$ which are supported by an alginate hydrogel impregnated with neurotrophic factors (NT-3 or BDNF with LIF, SMDF and MGF-1) to provide neuroprotection, stimulation of axonal growth and Schwann cell migration (Fig. 4a). After implantation into $12 \mathrm{~mm}$ sciatic nerve defect in rats for 4 weeks, patent regenerated nerves were observed, in which axons grew through and beyond the conduit. It was found that the aligned PLGA fibers support guided Schwann cell migration and neuron outgrowth [63]. This study shows that intelligent scaffold design that combines different manufacturing techniques, together with the incorporation of biological factors, can lead to favorable results. However, with the availability of more appropriate (biomaterial) fibers, the outcomes could be further improved.

The elastic structure of knits is useful where structures that have to adapt to size changes are required. Matsumara et al. implanted scaffolds made of PGA knitted fibers $+\mathrm{L}-$ lactide/ $\varepsilon$-caprolactone (PCL) copolymer sponge with outer PGA and PCL copolymer monofilament reinforcement into the inferior vena cava/left pulmonary artery of beagle dogs for potential application in pediatric cardiovascular surgery [155]. The initial strength of $9.3 \mathrm{~N}$ per $1 \mathrm{~cm}$ width was lost by 1 month; the scaffold was degraded by hydrolysis within 6 months, being replaced by native tissue. The scaffolds adapted their shapes after implantation, which is an important feature for its targeted use in pediatric surgery $[155,156]$. The authors also point out the cost-effective and time-saving procedure compared to a cell-based approach using the same biodegradable scaffold system which was already tested in clinical trials [157, 158]. However, the scaffold design was not optimized for the proliferation of vascular smooth muscle cells.

Mechanical stability and elasticity are among the most important scaffold-features for skin regeneration [54]. The use of fibrous structures enables the promotion of angiogenesis by mechanical stimulation in vivo [159]. In a cellfree approach, a warp knitted PLGA multifiber mesh (PLGAm) (25 filaments/yarn; $15 \mu \mathrm{m}$ filament $\varnothing$ ) was used to improve the mechanical stability of porous collagenchitosan sponges (CCS) [49]. Wet-state tensile strengths of 2.79 MPa could be achieved [159]. After implantation in full-thickness skin defects of rats, the PLGAm/CCS scaffolds inhibited wound contraction, effectively promoted cell infiltration, neotissue formation and blood vessel ingrowth. 8 weeks post-surgery, the tensile strength of the repaired skin reached up to $73 \%$ of normal skin [49].

\subsection{Woven scaffolds}

Compared to knits, woven fabrics may be designed to achieve higher tensile strength and less elasticity. Besides flat "2D" fabrics, 3D weaving technology allows for the generation of defined spatial geometries [160], which are widely used in fiber reinforced composite applications [33] and also in TE applications [39, 161-163]. With 3D weaving, the through-plane strength of woven fabrics can be improved considerably [32].

Most of the times, weaving techniques are used when high mechanical properties are required. Therefore, popular fields of applications are vascular grafts [147, 164], tendon regeneration [165] or hernia repair [59].

Yokota an colleagues designed the mechanical properties of a small-caliber vascular graft $(4 \mathrm{~mm} \varnothing)$ made of a type I bovine collagen microsponge compound with a cylindrically woven biodegradable and absorbable polymer tube (airspun core (PLA)-sheath (PGA) compound yarn), so that initial tensile modulus and tensile strength of the woven grafts (tensile strength: $\sim 30 \mathrm{MPa}$, modulus: $\sim 200 \mathrm{MPa}$ ) were much higher than of native carotid arteries (tensile strength: $\sim 8 \mathrm{MPa}$, modulus: $\sim 60 \mathrm{MPa}$ ) [164]. With absorption of the PGA fibers, tensile strength and modulus decreased to a level that was almost equivalent to that of the native carotid artery of mongrel dogs. An endothelial cell monolayer, smooth muscle cells and a reconstructed vessel wall with elastin and collagen fibers could be observed 12 months post-surgery [147, 164]. In another study concentrating on the mechanical properties, Derwin et al. used a commercially available woven PLA sheet (X-Repair) for the augmentation of rotator cuff defects in dogs [166]. They observed that directly after implantation the repair augmentation significantly increased the ultimate load by $23 \%$ compared to un-augmented repair, while the stiffness remained unaltered. At 12 weeks, the PLA scaffold augmented repairs demonstrated significantly less tendon retraction and significantly greater cross-sectional area (137 \%), stiffness (26\%), and ultimate load $(35 \%)$ than did repairs that had not been augmented [166]. The same material was also positively evaluated in an initial-load test of augmented human cadaver rotator cuffs [167].

Inui and co-workers studied different surface qualities of a cell free scaffold in a rabbit rotator cuff defect model [165]. They fabricated a woven fabric made of PLLA fibers with a smooth surface on the outside and a rough (pilefinished) surface on the inside [168]. The scaffolds were implanted into defects of the infraspinatus tendon. The rough surface allowed better cell migration while the smooth surface prevented cell attachment. No significant difference in ultimate failure load between scaffolds and 
the control group (reattached natural infraspinatus tendons) could be observed. 8 weeks post-surgery, the failure strength of intact infraspinatus tendons was regained [165]. This study shows that adjusting surface structures on the macroscopic level may be used to control cell adhesion and migration. The versatility of weaving technology to create 3D structures and fabrics with defined porous properties remain largely unexploited in studies using woven cell free scaffolds.

A cell-free scaffold system made of hand-woven meshes from native dragline silk of the spider Nephila spp. for appliance in hernia repair was developed by SchaeferNolte et al. [59]. To investigate their usage as fascia replacement material, the meshes and two compare groups (commercially available hernia meshes Ultrapro and Surgisis) were tied onto the paravertebral fascia of rats. The relative elongation of the spider-silk meshes was higher than the relative elongation of Ultrapro and Surgisis, demonstrating the spider-silks' superior adaptability to changing body shapes. Rapid cell migration into the spider silk meshes and milder immune responses than in the compare croup were registered. Complete degradation was observed after 4 months. However, the authors point out that the functionality of spider silk meshes has to be validated in real hernia models [59]. This study points out the usefulness of novel biomaterial fiber materials. At the same time, it becomes obvious that intensified research is necessary before such materials can be processed with textile manufacturing methods.

\subsection{Braided scaffolds}

Braiding generally leads to rope-like structures, either dense, hollow, or with embedded core fibers. More complex braiding techniques allow for the fabrication of 3D net-shaped structures [169]. Due to the fiber orientation in a specific angle to the braiding direction and the resulting mechanical properties of braided structures, braiding is among the most common scaffold fabrication techniques used in ligament TE [170].

Aurora et al. investigated PLLA/PGA braid reinforcement as a method for engineering the mechanical properties of lyophilized human fascia patches [171]. The authors conclude that the patch reinforcement may be sufficient to provide mechanical augmentation to rotator cuff repairs and minimize tendon retraction [171]. The same scaffold model (PLLA braid reinforced fascia) was used for rotator cuff repair in dogs [172]. While at time zero the ultimate load of the augmented repairs was $46 \pm 25 \%$ more than non-augmented repairs. However, the ultimate load did not increase with time [172]. Hence, the mechanical strength lost by scaffold degradation could not be compensated for by regenerated tissue. In another study, Cooper et al. used multifilament PLLA fibers fabricated into 3D square braids for ACL regeneration in rabbits [173]. Scaffolds seeded with ACL cells were compared to cell-free scaffolds. The initial tensile properties of the braided scaffolds were similar to that of native tissue. Poor tissue ingrowth was observed 4 weeks post-surgery. After 12 weeks, only the cell-seeded scaffolds showed excellent tissue infiltration and revascularization. The cell-seeded scaffolds also retained more of their tensile strength than the cell-free scaffolds [173].

The problems identified in the above-described studies may occur since the scaffolds were not consequently designed based on the requirements of the host tissue. The sole use of cell-free scaffolds without the incorporation of biological cues seems insufficient for ligament regeneration.

In the subject of nerve regeneration thorough research has been conducted on braided, collagen coated PGA tubes with incorporated collagen sponges or fibers. This scaffold type was successfully applied for the regeneration of various different types of nerves in animal models [174-178] prior to its use in clinical studies [179-181] (see "Clinical Studies"). The same workgroup also developed a nerve guide tube based on the well-established PGA-collagen scaffold for the repair of long nerve defects [50]. They used braided scaffolds of PLLA monofilaments and PGA multifilament yarns (1:1) with a collagen coating for the repair of long nerve defects in beagle dogs. Compared to scaffolds consisting of PGA-collagen only, the PLLA-PGA-collagen scaffolds led to faster functional recovery. The lumen structure which is necessary for nerve regeneration was maintained for 12 months. The tubular scaffolds also allowed for the development of normal tibialis anterior (TA) muscle cells [50].

\subsection{Non-woven scaffolds}

Since their pore size is accurately adjustable, non-woven fabrics are commonly used for filtration applications [35]. This beneficial property has also been exploited in TE applications, especially for cartilage engineering [182-185] and biomaterial evaluation [186-189]. As well as in classical TE approaches, along with the use of collagen-matrixes [190-192], non-woven fabrics are desirable materials for in situ cartilage regeneration.

Yokoya and co-workers developed a cell-free tendonbone insertion made of a PGA nonwoven sheet for the repair of full-thickness rotator cuff defects in rabbits [193]. Compared to a PCL scaffold used in a control group, the defect sites showed a well-arranged fibrocartilage layer, mainly regenerated by type III collagen. Mechanical examinations revealed significantly higher values in tensile strength [2.36 MPa (PGA) vs. $1.80 \mathrm{MPa}$ (PCL) after 16 weeks] and Young's modulus [5.53 MPa (PGA) vs. 3.74 MPa (PCL) after 16 weeks] [193]. Another scaffold 
system for rotator cuff regeneration consists of sheets of non-woven chitin fibers implanted into defects of the infraspinatus tendon [194]. Compared to untreated defects, the scaffolds increased cell numbers and improved collagen fiber alignment. However, the scaffolds possessed inadequate mechanical strength [194]. With a molding technique, Yang et al. fabricated non-woven nerve-guidance conduits made of bombyx mori silk fibroin oriented fibers cast in fibroin solution [195]. The grafts were used to bridge a $10 \mathrm{~mm}$ gap in sciatic nerves in rats. The scaffolds showed favorable maximum fracture strength (5.5 MPa) and compressive strength $(2.5 \mathrm{MPa})$ in the wet state. They could promote peripheral nerve regeneration. The authors suggest that introducing neurothropic factors could further improve the scaffold, thus becoming a real alternative for nerve autografts [195]. From the described studies, it becomes clear that researchers do not make adequate use of the possibility to adjust the porous properties of non-wovens. Designing the nonwovens based upon the relations of porosity and cell-material interaction should be considered in order to exploit the benefits given by non-wovens.

Zhu and colleagues pursued a design-approach for vascular grafts which allows vascular smooth muscle cells (VSMCs) infiltration and their circumferential alignment (Fig. 4c) [64]. Therefore, they fabricated a bi-layered scaffolds composed of wet-spun circular aligned PCLfibers covered with an electrospun PCL coating. They obtained vascular grafts with mechanical properties similar to native arteries of rats. The scaffold design plays a key role for the successful cellular integration: The large interconnected pores enabled the VSMCs to infiltrate the graft wall and the circumferentially aligned fibers served as topographical guidance [64].

\subsection{Clinical studies using cell-free fiber based scaffolds}

Similar to in vitro TE, there are comparatively few in situ TE approaches which have been evaluated in clinical studies. The demand on in situ TE as an approach that avoids the major disadvantages of classical in vitro TE and thus may be transferred to clinical application in a more straight forward way needs to be manifested in clinical case studies. Especially for nerve regeneration, cell-free fiber based scaffolds were successfully used in clinical case studies. The easy fabrication of tubes by textile manufacturing techniques and their possible off-the-shelve availability support their use as a cost-effective treatment of nerve defects. Vascular TE also benefits from fibrous tubes; however there are few clinical studies on in situ vascular TE [9]. This section describes promising clinical case studies using cell-free fiber based scaffolds.

Remarkable clinical application studies in the field of nerve regeneration were conducted by Inada et al. [181].
They developed a braided, collagen coated PGA tube filled with a collagen sponge (70-80\% collagen type I, 20-30\% collagen type III) for the regeneration of large peripheral motor/sensory nerve defects and for causalgia-treatment, respectively. The grafts had a PGA wall thickness of $50 \mu \mathrm{m}$ and tube-diameters of $4 \mathrm{~mm}$ and were used to bridge nerve gaps of up to $65 \mathrm{~mm}$ in length [174]. After implantation, the patients experienced functional recovery of their finger/foot [179], regained the voluntary ability to lift their eyebrow [181] and regained full use of their fingers after causalgia and allodynia had disappeared [180]. The authors conclude that their PGA/collagen scaffold is a promising option and viable alternative for conventional nerve grafts. In another clinical study on nerve-repair, Aberg and co-workers used non-wovens made of resorbable poly[(R)-3-hydroxybutyrate] (PHB) fibers for the treatment of complete median and/or ulnar nerve injuries at the wrist/forearm level by wrapping the PHB non-woven pads around the nerve ends in a tubelike fashion [196]. Compared to standard end-to-end suturing, the treatment with PHB non-wovens may be advantageous regarding sensory recovery and manual muscle tests. The authors point out, that the wrap-around technique also offers practical advantages to the surgeon [196]. Currently, with the Neurotube ${ }^{\mathrm{TM}}$ conduit (Synovis Life Technologies, St. Paul, USA) there is one commercially available and FDA approved nerve graft made of woven PGA fibers [197-199].

Fibrous cell-free scaffolds for in situ reconstruction of small joints were tested in clinical studies by Honkanen, Tiihonen et al. The scaffold system made of knitted ( $\mathrm{P}(\mathrm{L} /$ D)LA) fibers which was investigated by Waris et al. in a pig model [200] was used for the reconstruction of metacarpophalangeal joints in rheumatoid arthritis patients [201-203]. The knitted interposition scaffold was compared to Swanson silicone implants. After 2 years the improvement in clinical assessments was comparable in both groups, except for better maintenance of palmar alignment in the Swanson group. The lack of implant fractures and intramedullary osteolysis were advantages of the knitted implant [202]. After a mean follow-up of seven years, satisfactory pain relief was registered, but the function was limited. The patient satisfaction was similar in the silicone implant group and in the knitted implant group. The authors conclude that the main clinically relevant outcomes are similar and that due to soft tissue deficiencies long-term function and alignment problems cannot be resolved with PLDLA interposition implant [203]. In reconstruction of the destructed trapeziometacarpal joint in arthritic patients the $\mathrm{P}(\mathrm{L} / \mathrm{D}) \mathrm{LA})$ knitted scaffold was compared to tendon interposition [204]. The authors conclude that bioreplaceable interposition arthroplasty using the knitted scaffold works at least as well as tendon interposition and that the operation using the knitted scaffold is easier [204] 


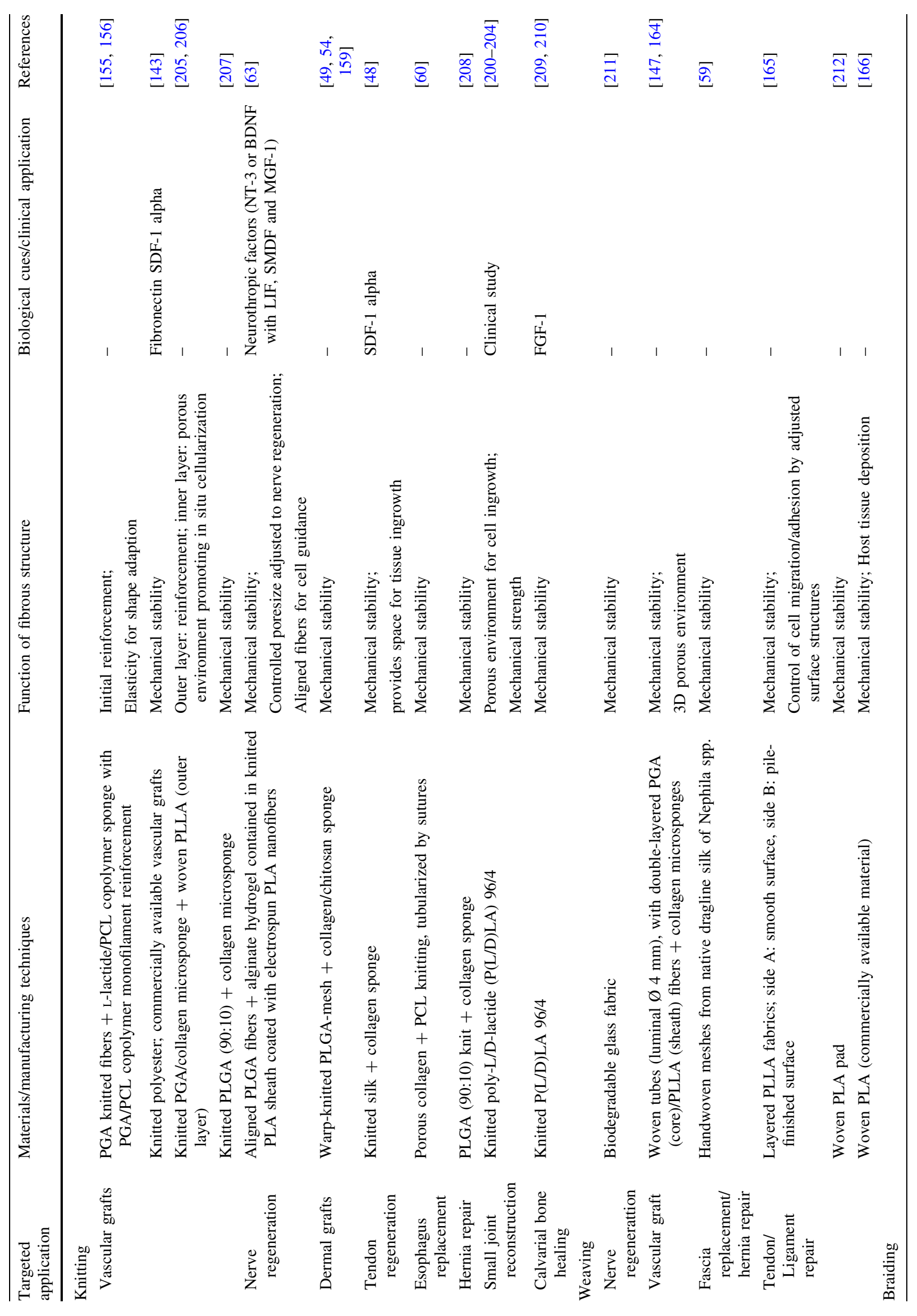




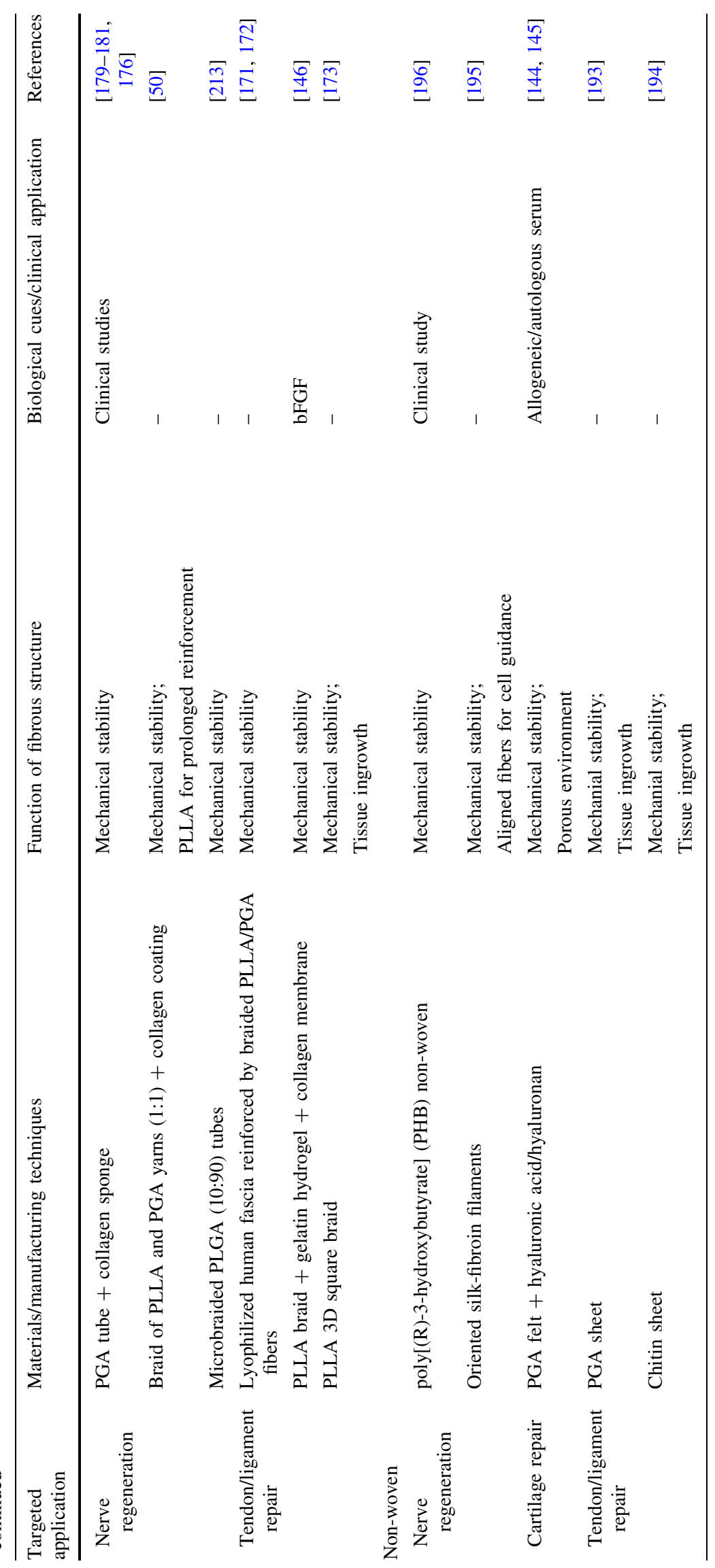




\section{Conclusion}

In this review, the preconditions and possibilities of textile manufacturing methods, fiber development and functionalization for the fabrication of cell-free scaffolds for in situ TE have been summarized. Studies in this field encompass a variety of engineered scaffolds from simple grafts [193] to complex multi-material scaffolds [63]. The basic benefits of fibrous scaffold architectures, namely mechanical stability, porosity and degradability, are employed in most cases. However, fibrous engineered scaffold systems stay behind the possibilities which are principally offered by textile manufacturing techniques and their combination with other manufacturing techniques. In order to make use of the whole range of favors, there are four main issues which need to be addressed: (1) Logical combination of manufacturing techniques and materials. (2) Biomaterial fiber development. (3) Adaption of textile manufacturing techniques to the demands of scaffolds for regenerative medicine. (4) Incorporation of biological cues (e.g. stem cell homing factors).

(1) A crucial premise for successful scaffold development is that the choice of material, manufacturing techniques and biological cues must be dictated by the targeted repair-tissue. The paradox of expert knowledge in specific techniques on the one hand and a broad overview about the huge variety of existing materials and techniques on the other hand may only be solved if intense interdisciplinary collaboration is consequently pursued. The combination of appropriate materials, manufacturing and functionalization techniques must be derived from the desired scaffold-properties [62].

(2) Besides the well-established synthetic polymers (e.g. PLA, PGA, PLGA, PBT), recent developments in biomaterial fiber engineering enable the exploitation of the favorable material properties from materials such as collagen, chitosan, regenerated silk or recombinant proteins in fibers suitable for their processing into stable spatial scaffolds $[51,80,116$, 117]. However, intensified studies concerning fiber properties and the in vitro and in vivo behavior of those newly developed fibers have to be conducted in order to use them for regenerative medicine. Furthermore, regulatory restrictions regarding the use of novel fibrous materials in the human body must be taken into account [12].

(3) The possibilities offered by textile manufacturing techniques to create structures with adjusted mechanical and porous properties may only be exploited if the manufacturing method is chosen based on the demands of the targeted tissue [30]. Manufacturing methods have to be adapted in order to allow the combination of the fibrous architecture with other materials (e.g. nano-fibers, hydrogels), thus creating structurally hierarchical "hybrid" scaffolds which match the host tissue. Also, techniques by which 3D net shaped geometries (similar to AM techniques) may be fabricated from fibers are to be further developed [47], thus allowing simple fabrication of custom-shaped and patient specific fibrous scaffolds.

(4) Especially for in situ TE, the incorporation and sustained release of biological cues into scaffolds is crucial for their successful application [2, 7]. Despite this fact, the incorporation of biological cues is not looked at in most cases when fiber-based cell-free scaffolds are used for in situ TE. A functioning fiber-based release-system for the sustained delivery of biological cues could help in achieving an important goal in guiding host cells to form a well-integrated functional structure [2]. Therefore, intensified research is necessary.

Depending on the type of engineered tissue and the application, clinical studies showed that cell-free fibrous scaffolds may be superior to or as well as conventional "gold standard" treatments [181, 196, 202]. Besides the obvious advantages of in situ TE (off-the-shelve scaffold availability, less cost and time consumption) it has to be considered that in terms of tissue ingrowth, tissue formation and regained functionality of regenerated tissue, cellfree fibrous scaffold systems do not always yield better results as their cell-seeded counterparts [173]. With the availability of novel biomaterial fibers with sufficient mechanical performance for textile manufacturing techniques and the appropriate addition and sustained release of cell homing factors and growth factors, in situ TE approaches using cell-free fibrous scaffolds could be elevated to various clinical applications. To make progress towards this goal, the interdisciplinary collaboration of experts in the fields of medicine, biomaterials science and textile engineering has to be consequently pursued.

Acknowledgment This research received no specific grant from any funding agency in the public, commercial, or not-for-profit sectors.

\section{Compliance with ethical standards}

Conflict of interest The authors declare that there is no conflict of interest.

Open Access This article is distributed under the terms of the Creative Commons Attribution 4.0 International License (http://crea tivecommons.org/licenses/by/4.0/), which permits unrestricted use, distribution, and reproduction in any medium, provided you give appropriate credit to the original author(s) and the source, provide a link to the Creative Commons license, and indicate if changes were made. 


\section{References}

1. Woodruff MA, Lange C, Reichert J, Berner A, Chen F, Fratzl P, et al. Bone tissue engineering: from bench to bedside. Mater Today. 2012;15:430-5.

2. Ko IK, Lee SJ, Atala A, Yoo JJ. In situ tissue regeneration through host stem cell recruitment. Exp Mol Med. 2013;45:e57. doi:10.1038/emm.2013.118.

3. Hollister SJ. Scaffold design and manufacturing: from concept to clinic. Adv Mater. 2009;21:3330-42. doi:10.1002/adma. 200802977.

4. Fioretta ES, Fledderus JO, Burakowska-Meise EA, Baaijens FPT, Verhaar MC, Bouten CVC. Polymer-based scaffold designs for in situ vascular tissue engineering: controlling recruitment and differentiation behavior of endothelial colony forming cells. Macromol. Biosci. 2012;12:577-90. doi:10.1002/ mabi.201100315.

5. Jakob F, Ebert R, Rudert M, Noeth U, Walles H, Docheva D, et al. In situ guided tissue regeneration in musculoskeletal diseases and aging Implementing pathology into tailored tissue engineering strategies. Cell Tissue Res. 2012;347:725-35. doi:10.1007/s00441-011-1237-z.

6. Janicki P, Richter W. New approaches for in situ regeneration and tissue engineering of bone. Dtsch $\mathrm{Z}$ Sportmed. 2012;63:30-5. doi:10.5960/dzsm.2011.064.

7. Chen F, Wu L, Zhang M, Zhang R, Sun H. Homing of endogenous stem/progenitor cells for in situ tissue regeneration: promises, strategies, and translational perspectives. Biomaterials. 2011;32:3189-209. doi:10.1016/j.biomaterials.2010.12.032.

8. Sengupta D, Waldman SD, Li S. From in vitro to in situ tissue engineering. Ann Biomed Eng. 2014;42:1537-45. doi:10.1007/ s10439-014-1022-8.

9. Li S, Sengupta D, Chien S. Vascular tissue engineering: from in vitro to in situ. Wiley Interdiscip Rev Syst Biol Med. 2014;6:61-76. doi:10.1002/wsbm.1246.

10. Bell J, Haycock J. Next generation nerve guides: materials, fabrication, growth factors, and cell delivery. Tissue Eng B Rev. 2012;18:116-28. doi:10.1089/ten.teb.2011.0498.

11. Bueno EM, Glowacki J. Cell-free and cell-based approaches for bone regeneration. Nat Rev Rheumatol. 2009;5:685-97. doi:10. 1038/nrrheum.2009.228

12. Williams DF. The biomaterials conundrum in tissue engineering. Tissue Eng Part A. 2014;20:1129-31. doi:10.1089/ten.tea. 2013.0769

13. Langer R, Vacanti JP. Tissue engineering. Science. 1993;260:920-6. doi:10.1126/science.8493529.

14. Liao CJ, Chen CF, Chen JH, Chiang SF, Lin YJ, Chang KY. Fabrication of porous biodegradable polymer scaffolds using a solvent merging/particulate leaching method. J Biomed Mater Res. 2002;59:676-81. doi:10.1002/jbm.10030.

15. Murphy WL, Dennis RG, Kileny JL, Mooney DJ. Salt fusion: an approach to improve pore interconnectivity within tissue engineering scaffolds. Tissue Eng. 2002;8:43-52. doi:10.1089/ 107632702753503045.

16. Hou QP, Grijpma DW, Feijen J. Porous polymeric structures for tissue engineering prepared by a coagulation, compression moulding and salt leaching technique. Biomaterials. 2003;24:1937-47. doi:10.1016/S0142-9612(02)00562-8.

17. Harris LD, Kim BS, Mooney DJ. Open pore biodegradable matrices formed with gas foaming. J Biomed Mater Res. 1998:42:396-402. doi:10.1002/(SICI)1097-4636(19981205)42: 3<396:AID-JBM7>3.0.CO;2-E.

18. Nam YS, Yoon JJ, Park TG. A novel fabrication method of macroporous biodegradable polymer scaffolds using gas foaming salt as a porogen additive. $\mathrm{J}$ Biomed Mater Res.
2000;53:1-7. doi:10.1002/(SICI)1097-4636(2000)53:1<1:AIDJBM1>3.0.CO;2-R.

19. Salerno A, Oliviero M, Di Maio E, Iannace S, Netti PA. Design of porous polymeric scaffolds by gas foaming of heterogeneous blends. J Mater Sci Mater Med. 2009;20:2043-51. doi:10.1007/ s10856-009-3767-4.

20. Nam YS, Park TG. Biodegradable polymeric microcellular foams by modified thermally induced phase separation method. Biomaterials. 1999;20:1783-90. doi:10.1016/S0142-9612(99)00073-3.

21. Akbarzadeh R, Yousefi A. Effects of processing parameters in thermally induced phase separation technique on porous architecture of scaffolds for bone tissue engineering. J Biomed Mater Res B Appl Biomater. 2014;102:1304-15. doi:10.1002/jbm.b.33101.

22. Ho MH, Kuo PY, Hsieh HJ, Hsien TY, Hou LT, Lai JY, et al. Preparation of porous scaffolds by using freeze-extraction and freeze-gelation methods. Biomaterials. 2004;25:129-38. doi:10. 1016/S0142-9612(03)00483-6.

23. Qian L, Zhang H. Controlled freezing and freeze drying: a versatile route for porous and micro-/nano-structured materials. J Chem Technol Biotechnol. 2011;86:172-84. doi:10.1002/jctb.2495.

24. Whang K, Thomas $\mathrm{CH}$, Healy KE, Nuber G. A novel method to fabricate bioabsorbable scaffolds. Polymer. 1995;36:837-42. doi:10.1016/0032-3861(95)93115-3.

25. Giannitelli SM, Accoto D, Trombetta M, Rainer A. Current trends in the design of scaffolds for computer-aided tissue engineering. Acta Biomater. 2014;10:580-94. doi:10.1016/j.act bio.2013.10.024.

26. Dalton PD, Vaquette C, Farrugia BL, Dargaville TR, Brown TD, Hutmacher DW. Electrospinning and additive manufacturing: converging technologies. Biomater Sci. 2013;1:171-85. doi:10. 1039/c2bm00039c.

27. Hollister SJ. Porous scaffold design for tissue engineering. Nat Mater. 2005;4:518-24. doi:10.1038/nmat1421.

28. Braghirolli DI, Steffens D, Pranke P. Electrospinning for regenerative medicine: a review of the main topics. Drug Discov Today. 2014;19:743-53. doi:10.1016/j.drudis.2014.03.024.

29. Ma ZW, Kotaki M, Inai R, Ramakrishna S. Potential of nanofiber matrix as tissue-engineering scaffolds. Tissue Eng. 2005;11:101-9. doi:10.1089/ten.2005.11.101.

30. Tamayol A, Akbari M, Annabi N, Paul A, Khademhosseini A, Juncker D. Fiber-based tissue engineering: progress, challenges, and opportunities. Biotechnol Adv. 2013;31:669-87. doi:10. 1016/j.biotechadv.2012.11.007.

31. Burdick JA, Mauck RL. Biomaterials for tissue engineering applications: a review of the past and future trends. Wien, New York: Springer; 2011.

32. Kamiya R, Cheeseman BA, Popper P, Chou TW. Some recent advances in the fabrication and design of three-dimensional textile preforms: a review. Compos Sci Technol. 2000;60:3347. doi:10.1016/S0266-3538(99)00093-7.

33. Cherif C. Textile Werkstoffe für den Leichtbau. Berlin: Springer; 2011

34. Pohl G. Textiles for construction. Oxford: Woodhead; 2009.

35. Kumar RS. Textiles for industrial applications. Boca Raton: CRC Press, Taylor \& Francis Group; 2014.

36. Behera BK, Arora H. Surgical gown: a critical review. J Ind Text. 2009;38:205-31. doi:10.1177/1528083708091251.

37. Wang X, Han C, Hu X, Sun H, You C, Gao C, et al. Applications of knitted mesh fabrication techniques to scaffolds for tissue engineering and regenerative medicine. J Mech Behav Biomed Mater. 2011;4:922-32. doi:10.1016/j.jmbbm.2011.04.009.

38. Gloy Y, Loehrer M, Lang B, Rongen L, Gries T, Jockenhoevel S. Tubular woven narrow fabrics for replacement of cruciate ligaments. Ann Biomed Eng. 2013;41:1950-6. doi:10.1007/ s10439-013-0806-6. 
39. Moutos FT, Freed LE, Guilak F. A biomimetic three-dimensional woven composite scaffold for functional tissue engineering of cartilage. Nat Mater. 2007;6:162-7. doi:10.1038/ nmat1822.

40. Ahn H, Kim KJ, Park SY, Huh JE, Kim HJ, Yu W. 3D braid scaffolds for regeneration of articular cartilage. J Mech Behav Biomed Mater. 2014;34:37-46. doi:10.1016/j.jmbbm.2014.01. 004.

41. Anitua E, Sanchez M, Orive G. Potential of endogenous regenerative technology for in situ regenerative medicine. Adv Drug Deliv Rev. 2010;62:741-52. doi:10.1016/j.addr.2010.01. 001.

42. Ribba L, Parisi M, D'Accorso NB, Goyanes S. Electrospun nanofibrous mats: from vascular repair to osteointegration. J Biomed Nanotechnol. 2014;10:3508-35. doi:10.1166/jbn.2014.2046.

43. Ingavle GC, Leach JK. Advancements in electrospinning of polymeric nanofibrous scaffolds for tissue engineering. Tissue Eng B Rev. 2014;20:277-93. doi:10.1089/ten.teb.2013.0276.

44. Johannsen $\mathrm{O}$. The history of the textile industry. Zeitschrift des Vereines Deutscher Ingenieure. 1932;76:710.

45. Wulfhorst B, Gries T, Veit D. Textile technology. München: Carl Hanser Verlag GmbH \& Co. KG; 2006.

46. Bettahalli NMS, Vicente J, Moroni L, Higuera GA, van Blitterswijk CA, Wessling $M$, et al. Integration of hollow fiber membranes improves nutrient supply in three-dimensional tissue constructs. Acta Biomater. 2011;7:3312-24. doi:10.1016/j.act bio.2011.06.012.

47. Hild M, Bruenler R, Jaeger M, Laourine E, Scheid L, Haupt D, et al. Net Shape Nonwoven: a novel technique for porous threedimensional nonwoven hybrid scaffolds. Text Res J. 2014;84:1084-94. doi:10.1177/0040517513515315.

48. Shen W, Chen X, Chen J, Yin Z, Heng BC, Chen W, et al. The effect of incorporation of exogenous stromal cell-derived factor1 alpha within a knitted silk-collagen sponge scaffold on tendon regeneration. Biomaterials. 2010;31:7239-49. doi:10.1016/j.bio materials.2010.05.040.

49. Wang X, You C, Xinlei Hu, Yurong Zheng, Qiyin Li, Zhanzeng Feng, et al. The roles of knitted mesh-reinforced collagen-chitosan hybrid scaffold in the one-step repair of full-thickness skin defects in rats. Acta Biomater. 2013;9:7822-32. doi:10.1016/j. actbio.2013.04.017.

50. Ichihara S, Inada Y, Nakada A, Endo K, Azuma T, Nakai R, et al. Development of new nerve guide tube for repair of long nerve defects. Tissue Eng C Methods. 2009;15:387-402. doi:10. 1089/ten.tec.2008.0508.

51. Toskas G, Bruenler R, Hund H, Hund R, Hild M, Aibibu D, et al. Pure chitosan microfibres for biomedical applications. Autex Res. J. 2013;13:134-40. doi:10.2478/v10304-012-0041-5.

52. Li X, Yang Y, Fan Y, Feng Q, Cui F, Watari F. Biocomposites reinforced by fibers or tubes as scaffolds for tissue engineering or regenerative medicine. $J$ Biomed Mater Res A. 2014;102:1580-94. doi:10.1002/jbm.a.34801.

53. McCullen SD, Haslauer CM, Loboa EG. Fiber-reinforced scaffolds for tissue engineering and regenerative medicine: use of traditional textile substrates to nanofibrous arrays. J Mater Chem. 2010;20:8776-88. doi:10.1039/c0jm01443e.

54. You C, Wang X, Zheng Y, Han C. Three types of dermal grafts in rats: the importance of mechanical property and structural design. Biomed Eng Online. 2013;12:125. doi:10.1186/1475925X-12-125.

55. Li X, Huang Y, Zheng L, Liu H, Niu X, Huang J, et al. Effect of substrate stiffness on the functions of rat bone marrow and adipose tissue derived mesenchymal stem cells in vitro. J Biomed Mater Res, Part A. 2014;102:1092-101. doi:10.1002/ jbm.a.34774.
56. Koufaki N, Ranella A, Aifantis KE, Barberoglou M, Psycharakis $\mathrm{S}$, Fotakis $\mathrm{C}$, et al. Controlling cell adhesion via replication of laser micro/nano-textured surfaces on polymers. Biofabrication. 2011;3:045004.

57. Hutmacher DW, Cool S. Concepts of scaffold-based tissue engineering-the rationale to use solid free-form fabrication techniques. J Cell Mol Med. 2007;11:654-69. doi:10.1111/j. 1582-4934.2007.00078.x.

58. Ogulata RT, Mezarcioz S. Total porosity, theoretical analysis, and prediction of the air permeability of woven fabrics. J Text Inst. 2012;103:654-61. doi:10.1080/00405000.2011.597567.

59. Schaefer-Nolte F, Hennecke K, Reimers K, Schnabel R, Allmeling C, Vogt PM, et al. Biomechanics and biocompatibility of woven spider silk meshes during remodeling in a rodent fascia replacement model. Ann Surg. 2014;259:781-92. doi:10. 1097/SLA.0b013e3182917677.

60. Hoogenkamp HR, Koens Martin J W, Geutjes PJ, Ainoedhofer $\mathrm{H}$, Wanten G, Tiemessen DM, et al. Seamless vascularized large-diameter tubular collagen scaffolds reinforced with polymer knittings for esophageal regenerative medicine. Tissue Eng C Methods. 2014;20:423-30. doi:10.1089/ten.tec.2013.0485.

61. Qian F, Denglong C, Zhiming Y, Min L. In vitro and in vivo research on using Antheraea pernyi silk fibroin as tissue engineering tendon scaffolds. Mater Sci Eng, C. 2009;29:1527-34. doi:10.1016/j.msec.2008.12.007.

62. Puppi D, Zhang X, Yang L, Chiellini F, Sun X, Chiellini E. Nano/microfibrous polymeric constructs loaded with bioactive agents and designed for tissue engineering applications: a review. J Biomed Mater Res B Appl Biomater. 2014;102:1562-79. doi:10.1002/jbm.b.33144.

63. Quigley AF, Bulluss KJ, Kyratzis ILB, Gilmore K, Mysore T, Schirmer KSU, et al. Engineering a multimodal nerve conduit for repair of injured peripheral nerve. J Neural Eng. 2013;10:016008. doi:10.1088/1741-2560/10/1/016008.

64. Zhu M, Wang Z, Zhang J, Wang L, Yang X, Chen J, et al. Circumferentially aligned fibers guided functional neoartery regeneration in vivo. Biomaterials. 2015;61:85-94. doi:10.1016/ j.biomaterials.2015.05.024.

65. Bramfeldt H, Sabra G, Centis V, Vermette P. Scaffold vascularization: a challenge for three-dimensional tissue engineering. Curr Med Chem. 2010;17:3944-67.

66. Rawal A, Mukhopadhyay S. 4-melt spinning of synthetic polymeric filaments. In: Zhang D, editor. Advances in filament yarn spinning of textiles and polymers. Oxford: Woodhead Publishing; 2014. p. 75-99. doi:10.1533/9780857099174.2.75.

67. Ozipek B, Karakas H. 9-Wet spinning of synthetic polymer fibers. In: Zhang D, editor. Advances in filament yarn spinning of textiles and polymers. Oxford: Woodhead Publishing; 2014. p. 174-86. doi:10.1533/9780857099174.2.174.

68. Bhardwaj N, Kundu SC. Electrospinning: a fascinating fiber fabrication technique. Biotechnol Adv. 2010;28:325-47. doi:10. 1016/j.biotechadv.2010.01.004.

69. Maleki H, Gharehaghaji AA, Criscenti G, Moroni L, Dijkstra PJ. The influence of process parameters on the properties of electrospun PLLA yarns studied by the response surface methodology. J Appl Polym Sci. 2015;132. doi:10.1002/app.41388.

70. He J, Qi K, Zhou Y, Cui S. Fabrication of continuous nanofiber yarn using novel multi-nozzle bubble electrospinning. Polym Int. 2014;63:1288-94. doi:10.1002/pi.4672.

71. Mandal Biman B, Kundu Subhas C. Biospinning by silkworms: silk fiber matrices for tissue engineering applications. Acta Biomater. 2010;6:360-71. doi:10.1016/j.actbio.2009.08.035.

72. Wan AC, Liao IC, Yim EK, Leong KW. Mechanism of fiber formation by interfacial polyelectrolyte complexation. Macromolecules. 2004;37:7019-25. doi:10.1021/ma0498868. 
73. Jun Y, Kang E, Chae S, Lee S. Microfluidic spinning of microand nano-scale fibers for tissue engineering. Lab Chip. 2014;14:2145-60. doi:10.1039/c3lc51414e.

74. Asti A, Gioglio L. Natural and synthetic biodegradable polymers: different scaffolds for cell expansion and tissue formation. Int J Artif Organs. 2014;37:187-205. doi:10.5301/ijao.5000307.

75. Cheng X, Gurkan UA, Dehen CJ, Tate MP, Hillhouse HW, Simpson GJ, et al. An electrochemical fabrication process for the assembly of anisotropically oriented collagen bundles. Biomaterials. 2008;29:3278-88. doi:10.1016/j.biomaterials.2008. 04.028 .

76. Balasubramanian P, Prabhakaran MP, Sireesha M, Ramakrishna S. Collagen in human tissues: structure, function, and biomedical implications from a tissue engineering perspective. In: abe a, kausch hh, moller $\mathrm{m}$, pasch h, editors. polymer compositespolyolefin fractionation-polymeric peptidomimetics-collagens. heidelberger plaTZ 3, D-14197 Berlin, Germany. Springer, Berlin; 2013. p. 173-206. doi:10.1007/12_2012_176.

77. Kasoju N, Bora U. Silk fibroin in tissue engineering. Adv Healthc Mater. 2012;1:393-412. doi:10.1002/adhm.201200097.

78. Jayakumar R, Prabaharan M, Muzzarelli RA, editors. Chitosan for biomaterials II. Heidelberger platz 3, D-14197 Berlin, Germany. Springer, Berlin; 2011.

79. Altman GH, Diaz F, Jakuba C, Calabro T, Horan RL, Chen J, et al. Silk-based biomaterials. Biomaterials. 2003;24:401-16. doi:10.1016/S0142-9612(02)00353-8.

80. Younesi M, Islam A, Kishore V, Anderson JM, Akkus O. Tenogenic induction of human MSCs by anisotropically aligned collagen biotextiles. Adv Funct Mater. 2014;24:5762-70. doi:10.1002/adfm.201400828.

81. Cen L, Liu W, Cui L, Zhang W, Cao Y. Collagen Tissue engineering: development of novel biomaterials and applications. Pediatr Res. 2008;63:492-6.

82. Parenteau-Bareil R, Gauvin R, Berthod F. Collagen-based biomaterials for tissue engineering applications. Materials. 2010;3:1863-87. doi:10.3390/ma3031863.

83. Kew SJ, Gwynne JH, Enea D, Abu-Rub M, Pandit A, Zeugolis $\mathrm{D}$, et al. Regeneration and repair of tendon and ligament tissue using collagen fibre biomaterials. Acta Biomater. 2011;7:3237-47. doi:10.1016/j.actbio.2011.06.002.

84. Kato YP, Christiansen DL, Hahn RA, Shieh S, Goldstein JD, Silver FH. Mechanical properties of collagen fibres: a comparison of reconstituted and rat tail tendon fibres. Biomaterials. 1989;10:38-42. doi:10.1016/0142-9612(89)90007-0.

85. Pins GD, Christiansen DL, Patel R, Silver FH. Self-assembly of collagen fibers. Influence of fibrillar alignment and decorin on mechanical properties. Biophys J. 1997;73:2164-72.

86. Cavallaro JF, Kemp PD, Kraus KH. Collagen fabrics as biomaterials. Biotechnol Bioeng. 1994;44:146. doi:10.1002/bit. 260440121.

87. Zeugolis DI, Paul RG, Attenburrow G. Engineering extruded collagen fibers for biomedical applications. J Appl Polym Sci. 2008;108:2886-94. doi:10.1002/app.27208.

88. Zeugolis DI, Paul RG, Attenburrow G. Extruded collagenpolyethylene glycol fibers for tissue engineering applications. J Biomed Mater Res B Appl Biomater. 2008;85B:343-52. doi:10.1002/jbm.b.30952.

89. Zeugolis DI, Paul RG, Attenburrow G. Factors influencing the properties of reconstituted collagen fibers prior to self-assembly: animal species and collagen extraction method. J Biomed Mater Res, Part A. 2008;86A:892-904. doi:10.1002/jbm.a.31694.

90. Zeugolis DI, Paul GR, Attenburrow G. Cross-linking of extruded collagen fibers-A biomimetic three-dimensional scaffold for tissue engineering applications. J Biomed Mater Res Part A. 2009;89A:895-908. doi:10.1002/jbm.a.32031.
91. Caves JM, Kumar VA, Wen J, Cui W, Martinez A, Apkarian R, et al. Fibrillogenesis in Continuously Spun Synthetic Collagen Fiber. J Biomed Mater Res B Appl Biomater. 2010;93B:24-38. doi:10.1002/jbm.b.31555.

92. Kew SJ, Gwynne JH, Enea D, Brookes R, Rushton N, Best SM, et al. Synthetic collagen fascicles for the regeneration of tendon tissue. Acta Biomater. 2012;8:3723-31. doi:10.1016/j.actbio. 2012.06.018.

93. Enea D, Gwynne J, Kew S, Arumugam M, Shepherd J, Brooks $\mathrm{R}$, et al. Collagen fibre implant for tendon and ligament biological augmentation. In vivo study in an ovine model. Knee Surg Sports Traumatol Arthrosc. 2013;21:1783-93. doi:10. 1007/s00167-012-2102-7.

94. Shepherd JH, Ghose S, Kew SJ, Moavenian A, Best SM, Cameron RE. Effect of fiber crosslinking on collagen-fiber reinforced collagen-chondroitin-6-sulfate materials for regenerating load-bearing soft tissues. J Biomed Mater Res Part A. 2013;101A:176-84. doi:10.1002/jbm.a.34317.

95. Shepherd DV, Shepherd JH, Ghose S, Kew SJ, Cameron RE, Best SM. The process of EDC-NHS cross-linking of reconstituted collagen fibres increases collagen fibrillar order and alignment. APL Mater. 2015;3:014902. doi:10.1063/1.4900887.

96. Enea D, Henson F, Kew S, Wardale J, Getgood A, Brooks R, et al. Extruded collagen fibres for tissue engineering applications: effect of crosslinking method on mechanical and biological properties. J Mater Sci Mater Med. 2011;22:1569-78. doi:10.1007/s10856-011-4336-1.

97. Meyer M, Baltzer H, Schwikal K. Collagen fibres by thermoplastic and wet spinning. Mater Sci Eng C Mater Biol Appl. 2010;30:1266-71. doi:10.1016/j.msec.2010.07.005.

98. Uquillas JA, Kishore V, Akkus O. Genipin crosslinking elevates the strength of electrochemically aligned collagen to the level of tendons. J Mech Behav Biomed Mater. 2012;15:176-89. doi:10. 1016/j.jmbbm.2012.06.012.

99. Delgado LM, Bayon Y, Pandit A, Zeugolis DI. To cross-link or not to cross-link? cross-linking associated foreign body response of collagen-based devices. Tissue Eng B Rev. 2015;21:298-313. doi:10.1089/ten.teb.2014.0290.

100. Guan J, Yang J, Dai J, Qin Y, Wang Y, Guo Y, et al. Bioinspired nanostructured hydroxyapatite/collagen three-dimensional porous scaffolds for bone tissue engineering. RSC Adv. 2015;5:36175-84. doi:10.1039/c5ra01487e.

101. He N, Ke Q, Huang C, Yang J, Guo Y. Needle- punched nonwoven matrix from regenerated collagen fiber for cartilage tissue engineering. J Appl Polym Sci. 2014;131. doi:10.1002/app.40404.

102. Anitha A, Sowmya S, Kumar PT, Sudheesh Deepthi S, Chennazhi KP, Ehrlich $\mathrm{H}$, et al. Chitin and chitosan in selected biomedical applications. Prog Polym Sci. 2014;39:1644-67. doi:10.1016/j.progpolymsci.2014.02.008.

103. Riva R, Ragelle H, Des Rieux A, Duhem N, Jerome C, Preat V. Chitosan and chitosan derivatives in drug delivery and tissue engineering. In: Jayakumar R, Prabaharan M, Muzzarelli RA, editors. Chitosan for biomaterials II. Heidelberger platz 3, D-14197 Berlin, Germany. Springer, Berlin; 2011. p. 19-44. doi:10.1007/12_2011_137.

104. Elsabee MZ, Naguib HF, Morsi RE. Chitosan based nanofibers, review. Mater Sci Eng C Mater Biol Appl. 2012;32:1711-26. doi:10.1016/j.msec.2012.05.009.

105. Lee BR, Lee KH, Kang E, Kim D, Lee S. Microfluidic wet spinning of chitosan-alginate microfibers and encapsulation of HepG2 cells in fibers. Biomicrofluidics. 2011;5:022208. doi:10. 1063/1.3576903.

106. Albanna MZ, Bou-Akl TH, Blowytsky O, Walters III, Henry L, Matthew HWT. Chitosan fibers with improved biological and mechanical properties for tissue engineering applications. 
J Mech Behav Biomed Mater. 2013;20:217-26. doi:10.1016/j. jmbbm.2012.09.012.

107. Desorme M, Montembault A, Lucas J, Rochas C, Bouet T, David L. Spinning of hydroalcoholic chitosan solutions. Carbohydr Polym. 2013;98:50-63. doi:10.1016/j.carbpol.2013.04. 070 .

108. Iwasaki N, Kasahara Y, Yamane S, Igarashi T, Minami A, Nisimura S. Chitosan-based hyaluronic acid hybrid polymer fibers as a scaffold biomaterial for cartilage tissue engineering. Polymers. 2011;3:100-13. doi:10.3390/polym3010100.

109. Li L, Yuan B, Liu S, Yu S, Xie C, Liu F, et al. Preparation of high strength chitosan fibers by using ionic liquid as spinning solution. J Mater Chem. 2012;22:8585-93. doi:10.1039/ C2JM30555K.

110. Yan W, Shen L, Ji Y, Yang Q, Shen X. Chitin nanocrystal reinforced wet-spun chitosan fibers. J Appl Polym Sci. 2014;131. doi:10.1002/app.40852.

111. Yudin VE, Dobrovolskaya IP, Neelov IM, Dresvyanina EN, Popryadukhin PV, Ivan'kova EM, et al. Wet spinning of fibers made of chitosan and chitin nanofibrils. Carbohydr Polym. 2014;108:176-82. doi:10.1016/j.carbpol.2014.02.090.

112. Hild M, Toskas G, Aibibu D, Wittenburg G, Meissner H, Cherif $\mathrm{C}$, et al. Chitosan/gelatin micro/nanofiber 3D composite scaffolds for regenerative medicine. Compos Interfaces. 2014;21:301-8. doi:10.1080/15685543.2014.852016.

113. Yamane S, Iwasaki N, Majima T, Funakoshi T, Masuko T, Harada K, et al. Feasibility of chitosan-based hyaluronic acid hybrid biomaterial for a novel scaffold in cartilage tissue engineering. Biomaterials. 2005;26:611-9. doi:10.1016/j.biomater ials.2004.03.013.

114. Yamane S, Iwasaki N, Kasahara Y, Harada K, Majima T, Monde $\mathrm{K}$, et al. Effect of pore size on in vitro cartilage formation using chitosan-based hyaluronic acid hybrid polymer fibers. J Biomed Mater Res, Part A. 2007;81A:586-93. doi:10. 1002/jbm.a.31095.

115. Kasahara $\mathrm{Y}$, Iwasaki N, Yamane S, Igarashi T, Majima T, Nonaka $S$, et al. Development of mature cartilage constructs using novel three-dimensional porous scaffolds for enhanced repair of osteochondral defects. J Biomed Mater Res Part A. 2008;86A:127-36. doi:10.1002/jbm.a.31259.

116. Li Z, Ji S, Wang Y, Shen X, Liang H. Silk fibroin-based scaffolds for tissue engineering. Front Mater Sci. 2013;7:237-47. doi:10.1007/s11706-013-0214-8.

117. Schacht K, Scheibel T. Processing of recombinant spider silk proteins into tailor-made materials for biomaterials applications. Curr Opin Biotechnol. 2014;29:62-9. doi:10.1016/j.copbio. 2014.02.015.

118. Chung DE, Um IC. Effect of molecular weight and concentration on crystallinity and post drawing of wet spun silk fibroin fiber. Fibers Polym. 2014;15:153-60. doi:10.1007/s12221-0140153-8.

119. Ki CS, Lee KH, Baek DH, Hattori M, Urn IC, Ihm DW, et al. Dissolution and wet spinning of silk fibroin using phosphoric acid/formic acid mixture solvent system. J Appl Polym Sci. 2007;105:1605-10. doi:10.1002/app.26176.

120. Ling S, Zhou L, Zhou W, Shao Z, Chen X. Conformation transition kinetics and spinnability of regenerated silk fibroin with glycol, glycerol and polyethylene glycol. Mater Lett. 2012;81:13-5. doi:10.1016/j.matlet.2012.04.136.

121. Zhou H, Shao Z, Chen X. Wet-spinning of regenerated silk fiber from aqueous silk fibroin solutions: influence of calcium ion addition in spinning dope on the performance of regenerated silk fiber. Chin J Polym Sci. 2014;32:29-34. doi:10.1007/s10118014-1368-2.

122. Yan J, Zhou G, Knight DP, Shao Z, Chen X. Wet-spinning of regenerated silk fiber from aqueous silk fibroin solution: discussion of spinning parameters. Biomacromolecules. 2010;11:1-5. doi:10.1021/bm900840h.

123. Zhang C, Song D, Lu Q, Hu X, Kaplan DL, Zhu H. Flexibility regeneration of silk fibroin in vitro. Biomacromolecules. 2012;13:2148-53. doi:10.1021/bm300541g.

124. Piri N, Mottaghitalab V, Arbab S. Conductive regenerated silk fibroin composite fiber containing MWNTs. E-Polym. 2013;13:007.

125. Koyanagi R, Zhu Z, Asakura T. Regenerated Bombyx mori silk fiber with enhanced biodegradability. J Insect Biotechnol Sericol. 2010;79:27-30.

126. Ittah S, Cohen S, Garty S, Cohn D, Gat U. An essential role for the C-terminal domain of a dragline spider silk protein in directing fiber formation. Biomacromolecules. 2006;7:1790-5. doi:10.1021/bm060120k.

127. Stark M, Grip S, Rising A, Hedhammar M, Engström W, Hjälm $\mathrm{G}$, et al. Macroscopic fibers self-assembled from recombinant miniature spider silk proteins. Biomacromolecules. 2007;8:1695-701. doi:10.1021/bm070049y.

128. Xu L, Rainey JK, Meng Q, Liu X. Recombinant minimalist spider wrapping silk proteins capable of native-like fiber formation. Plos One. 2012;7:e50227. doi:10.1371/journal.pone. 0050227.

129. Lazaris A, Arcidiacono S, Huang Y, Zhou J, Duguay F, Chretien $\mathrm{N}$, et al. Spider silk fibers spun from soluble recombinant silk produced in mammalian cells. Science. 2002;295:472-6. doi:10. 1126/science. 1065780.

130. Hsia Y, Gnesa E, Pacheco R, Kohler K, Jeffery F, Vierra C. Synthetic spider silk production on a laboratory scale. J Vis Exp: JoVE. 2012;65:e4191. doi:10.3791/4191.

131. Xia X, Qian Z, Ki CS, Park YH, Kaplan DL, Lee SY. Nativesized recombinant spider silk protein produced in metabolically engineered Escherichia coli results in a strong fiber. Proc Natl Acad Sci USA. 2010;107:14059-63. doi:10.1073/pnas. 1003366107.

132. Qiu W, Teng W, Cappello J, Wu X. Wet-spinning of recombinant silk-elastin-like protein polymer fibers with high tensile strength and high deformability. Biomacromolecules. 2009;10:602-8. doi:10.1021/bm801296r.

133. Meier C, Welland ME. Wet-spinning of amyloid protein nanofibers into multifunctional high-performance biofibers. Biomacromolecules. 2011;12:3453-9. doi:10.1021/bm2005752.

134. Weisman S, Haritos VS, Church JS, Huson MG, Mudie ST, Rodgers Andrew J W, et al. Honeybee silk: recombinant protein production, assembly and fiber spinning. Biomaterials. 2010;31:2695-700. doi:10.1016/j.biomaterials.2009.12.021.

135. Xu H, Cai S, Xu L, Yang Y. Water-stable three-dimensional ultrafine fibrous scaffolds from keratin for cartilage tissue engineering. Langmuir. 2014;30:8461-70. doi:10.1021/la500768b.

136. Goonoo N, Bhaw-Luximon A, Jhurry D. Drug loading and release from electrospun biodegradable nanofibers. J Biomed Nanotechnol. 2014;10:2173-99. doi:10.1166/jbn.2014.1885.

137. McNeil SE, Griffiths HR, Perrie Y. Polycaprolactone fibres as a potential delivery system for collagen to support bone regeneration. Curr Drug Deliv. 2011;8:448-55.

138. Seib FP, Kaplan DL. Silk for drug delivery applications: opportunities and challenges. Isr J Chem. 2013;53:756-66. doi:10.1002/ijch.201300083.

139. Trachtenberg JE, Mountziaris PM, Kasper FK, Mikos AG. Fiber-based composite tissue engineering scaffolds for drug delivery. Isr J Chem. 2013;53:646-54. doi:10.1002/ijch. 201300051.

140. Tuin SA, Pourdeyhimi B, Loboa EG. Interconnected, microporous hollow fibers for tissue engineering: commercially relevant, industry standard scale-up manufacturing. J Biomed Mater Res Part A. 2014;102:3311-23. doi:10.1002/jbm.a.35002. 
141. Ko YG, Choi US. Diverse applications of fibers surface-functionalized with nano- and microparticles. Compos Sci Technol. 2013;79:77-86. doi:10.1016/j.compscitech.2013.02.016.

142. Jassal M, Sengupta S, Warner SB, Bhowmick S. Quantitative characterization of functionally modified micron-submicron fibers for tissue regeneration: a review. Text Res J. 2013;83: 1999-2022. doi:10.1177/0040517513481870.

143. de Visscher G, Mesure L, Meuris B, Ivanova A, Flameng W. Improved endothelialization and reduced thrombosis by coating a synthetic vascular graft with fibronectin and stem cell homing factor SDF-1 alpha. Acta Biomater. 2012;8:1330-8. doi:10. 1016/j.actbio.2011.09.016.

144. Erggelet C, Neumann K, Endres M, Haberstroh K, Sittinger M, Kaps C. Regeneration of ovine articular cartilage defects by cell-free polymer-based implants. Biomaterials. 2007;28:557080. doi:10.1016/j.biomaterials.2007.09.005.

145. Abbushi A, Endres M, Cabraja M, Kroppenstedt SN, Thomale UW, Sittinger M, et al. Regeneration of intervertebral disc tissue by resorbable cell-free polyglycolic acid-based implants in a rabbit model of disc degeneration. Spine. 2008;33:1527-32.

146. Kimura Y, Hokugo A, Takamoto T, Tabata Y, Kurosawa H. Regeneration of anterior cruciate ligament by biodegradable scaffold combined with local controlled release of basic fibroblast growth factor and collagen wrapping. Tissue Eng C Methods. 2008;14:47-57. doi:10.1089/tec.2007.0286.

147. Takahashi H, Yokota T, Uchimura E, Miyagawa S, Ota T, Torikai K, et al. Newly developed tissue-engineered material for reconstruction of vascular wall without cell seeding. Ann Thorac Surg. 2009;88:1269-76. doi:10.1016/j.athoracsur.2009.04. 087.

148. Weber M, Heta E, Moreira R, Gesche VN, Schermer T, Frese J, et al. Tissue-engineered fibrin-based heart valve with a tubular leaflet design. Tissue Eng C Methods. 2014;20:265-75. doi:10. 1089/ten.tec.2013.0258.

149. Abounaim MD, Cherif C. Flat-knitted innovative three-dimensional spacer fabrics: a competitive solution for lightweight composite applications. Text Res J. 2012;82:288-98. doi:10. $1177 / 0040517511426609$.

150. Gokarneshan N, Varadarajan B, Kumar CB, Sentil BK, Rachel A. Engineering knits for versatile technical applications: some insights on recent researches. J Ind Text. 2012;42:52-75. doi:10. $1177 / 1528083711426021$.

151. Wintermantel E, Mayer J, Blum J, Eckert K, Lüscher P, Mathey M. Tissue engineering scaffolds using superstructures. Biomaterials. 1996;17:83-91. doi:10.1016/0142-9612(96)85753-X.

152. Yeoman MS, Reddy D, Bowles HC, Bezuidenhout D, Zilla P, Franz T. A constitutive model for the warp-weft coupled nonlinear behavior of knitted biomedical textiles. Biomaterials. 2010;31:8484-93. doi:10.1016/j.biomaterials.2010.07.033.

153. Peniston SJ, Burg KJL, Shalaby SW. Effect of mesh construction on the physicomechanical properties of bicomponent knit mesh using yarns derived from degradable copolyesters. J Biomed Mater Res B Appl Biomater. 2012;100B:1922-34. doi:10.1002/jbm.b.32759.

154. Vleggeert-Lankamp C, de Ruiter G, Wolfs J, Pêgo AP, van den Berg RJ, Feirabend H, et al. Pores in synthetic nerve conduits are beneficial to regeneration. J Biomed Mater Res, Part A. 2007;80A:965-82. doi:10.1002/jbm.a.30941.

155. Matsumura G, Isayama N, Matsuda S, Taki K, Sakamoto $Y$, Ikada $\mathrm{Y}$, et al. Long-term results of cell-free biodegradable scaffolds for in situ tissue engineering of pulmonary artery in a canine model. Biomaterials. 2013;34:6422-8. doi:10.1016/j.bio materials.2013.05.037.

156. Matsumura G, Nitta N, Matsuda S, Sakamoto Y, Isayama N, Yamazaki K, et al. Long-term results of cell-free biodegradable scaffolds for in situ tissue-engineering vasculature: in a canine inferior vena cava model. PLoS ONE. 2012;7:e35760. doi:10. 1371/journal.pone.0035760.

157. Hibino N, McGillicuddy E, Matsumura G, Ichihara Y, Naito Y, Breuer $\mathrm{C}$, et al. Late-term results of tissue-engineered vascular grafts in humans. J Thorac Cardiovasc Surg. 2010;139(431436):e2. doi:10.1016/j.jtcvs.2009.09.057.

158. Matsumura G, Hibino N, Ikada Y, Kurosawa H, Shin'oka T. Successful application of tissue engineered vascular autografts: clinical experience. Biomaterials. 2003;24:2303-8. doi:10.1016/ S0142-9612(03)00043-7.

159. Wang X, Li Q, Xinlei Hu, Lie Ma, Chuangang You, Yurong Zheng, et al. Fabrication and characterization of poly(L-lactideco-glycolide) knitted mesh-reinforced collagen-chitosan hybrid scaffolds for dermal tissue engineering. J Mech Behav Biomed Mater. 2012;8:204-15. doi:10.1016/j.jmddm.2012.01.001.

160. Ansar M, Xinwei W, Chouwei Z. Modeling strategies of 3D woven composites: a review. Compos Struct. 2011;93:1947-63. doi:10.1016/j.compstruct.2011.03.010.

161. Brunger JM, Huynh Nguyen P T, Guenther CM, Perez-Pinera P, Moutos FT, Sanchez-Adams J, et al. Scaffold-mediated lentiviral transduction for functional tissue engineering of cartilage. Proc Natl Acad Sci USA. 2014;111:E798. doi:10.1073/pnas. 1321744111.

162. Glass KA, Link JM, Brunger JM, Moutos FT, Gersbach CA, Guilak F. Tissue-engineered cartilage with inducible and tunable immunomodulatory properties. Biomaterials. 2014;35:5921-31. doi:10.1016/j.biomaterials.2014.03.073.

163. Liao I, Moutos FT, Estes BT, Zhao X, Guilak F. Composite threedimensional woven scaffolds with interpenetrating network hydrogels to create functional synthetic articular cartilage. Adv Funct Mater. 2013;23:5833-9. doi:10.1002/adfm.201300483.

164. Yokota T, Ichikawa H, Matsumiya G, Kuratani T, Sakaguchi T, Iwai $\mathrm{S}$, et al. In situ tissue regeneration using a novel tissueengineered, small-caliber vascular graft without cell seeding. J Thorac Cardiovasc Surg. 2008;136:900-7. doi:10.1016/j.jtcvs. 2008.02.058.

165. Inui A, Kokubu T, Fujioka H, Nagura I, Sakata R, Nishimoto H, et al. Application of layered poly (L-lactic acid) cell free scaffold in a rabbit rotator cuff defect model. Sports Med Arthrosc Rehabil Ther Technol: SMARTT. 2011;3:29. doi:10.1186/17582555-3-29.

166. Derwin KA, Codsi MJ, Milks RA, Baker AR, McCarron JA, Iannotti JP. Rotator cuff repair augmentation in a canine model with use of a woven poly-L-lactide device. J Bone Joint Surg Am Vol. 2009;91A:1159-71. doi:10.2106/JBJS.H.00775.

167. McCarron JA, Milks RA, Chen X, Iannotti JP, Derwin KA. Improved time-zero biomechanical properties using poly-Llactic acid graft augmentation in a cadaveric rotator cuff repair model. J Shoulder Elbow Surg. 2010;19:688-96. doi:10.1016/j. jse.2009.12.008.

168. Inui A, Kokubu T, Makino T, Nagura I, Toyokawa N, Sakata R, et al. Potency of double-layered Poly L-lactic Acid scaffold in tissue engineering of tendon tissue. Int Orthop. 2010;34:1327-32. doi:10.1007/s00264-009-0917-8.

169. Bilisik K. Three-dimensional braiding for composites: a review. Text Res J. 2013;83:1414-36. doi:10.1177/0040517512450766.

170. Leong NL, Petrigliano FA, McAllister DR. Current tissue engineering strategies in anterior cruciate ligament reconstruction. J Biomed Mater Res Part A. 2014;102:1614-24. doi:10. 1002/jbm.a.34820.

171. Aurora A, Mesiha M, Tan CD, Walker E, Sahoo S, Iannotti JP, et al. Mechanical characterization and biocompatibility of a novel reinforced fascia patch for rotator cuff repair. J Biomed Mater Res, Part A. 2011;99A:221-30. doi:10.1002/jbm.a.33179.

172. Baker AR, McCarron JA, Tan CD, Iannotti JP, Derwin KA. Does augmentation with a reinforced fascia patch improve 
rotator cuff repair outcomes? Clin Orthop Relat Res. 2012;470:2513-21. doi:10.1007/s11999-012-2348-x.

173. Cooper JA Jr, Sahota JS, Gorum WJ II, Carter J, Doty SB, Laurencin CT. Biomimetic tissue-engineered anterior cruciate ligament replacement. Proc Natl Acad Sci USA. 2007;104: 3049-54. doi:10.1073/pnas.0608837104.

174. Matsumoto K, Ohnishi K, Kiyotani T, Sekine T, Ueda H, Nakamura $\mathrm{T}$, et al. Peripheral nerve regeneration across an 80-mm gap bridged by a polyglycolic acid (PGA)-collagen tube filled with laminin-coated collagen fibers: a histological and electrophysiological evaluation of regenerated nerves. Brain Res. 2000;868:315-28. doi:10.1016/S0006-8993(00)02207-1.

175. Toba T, Nakamura T, Shimizu Y, Matsumoto K, Ohnishi K, Fukuda S, et al. Regeneration of canine peroneal nerve with the use of a polyglycolic acid-collagen tube filled with lamininsoaked collagen sponge: a comparative study of collagen sponge and collagen fibers as filling materials for nerve conduits. J Biomed Mater Res. 2001;58:622-30. doi:10.1002/jbm.1061.

176. Yoshitani M, Fukuda S, Itoi S, Morino S, Tao H, Nakada A, et al. Experimental repair of phrenic nerve using a polyglycolic acid and collagen tube. J Thorac Cardiovasc Surg. 2007;133:726-32. doi:10.1016/j.jtcvs.2006.08.089.

177. Kiyotani Tetsuya, Teramachi Masayoshi, Takimoto Yukinobu, Nakamura Tatsuo, Shimizu Yasuhiko, Endo Katsuaki. Nerve regeneration across a $25-\mathrm{mm}$ gap bridged by a polyglycolic acid-collagen tube: a histological and electrophysiological evaluation of regenerated nerves. Brain Res. 1996;740:66-74. doi:10.1016/S0006-8993(96)00848-7.

178. Nakamura T, Inada Y, Fukuda S, Yoshitani M, Nakada A, Itoi S, et al. Experimental study on the regeneration of peripheral nerve gaps through a polyglycolic acid-collagen (PGA-collagen) tube. Brain Res. 2004;1027:18-29. doi:10.1016/j.brainres.2004.08.040.

179. Inada Y, Morimoto S, Takakura Y, Nakamura T. Regeneration of peripheral nerve gaps with a polyglycolic acid-collagen tube. Neurosurgery. 2004;55:640-6. doi:10.1227/01.NEU.00001343 88.86603.11.

180. Inada Y, Morimoto S, Moroi K, Endo K, Nakamura T. Surgical relief of causalgia with an artificial nerve guide tube: successful surgical treatment of causalgia (Complex Regional Pain Syndrome Type II) by in situ tissue engineering with a polyglycolic acid-collagen tube. Pain. 2005;117:251-8. doi:10.1016/j.pain. 2005.05.033

181. Inada Y, Hosoi H, Yamashita A, Morimoto S, Tatsumi H, Notazawa S, et al. Regeneration of peripheral motor nerve gaps with a polyglycolic acid-collagen tube: technical case report. Neurosurgery. 2007;61:E1105.

182. Oliveira JT, Crawford A, Mundy JL, Sol PC, Correlo VM, Bhattacharya M, et al. Novel melt-processable chitosan-polybutylene succinate fibre scaffolds for cartilage tissue engineering. J Biomater Sci Polym Ed. 2011;22:773-88. doi:10.1163/ $092050610 X 494604$.

183. Rampichova M, Kostakova E, Filova E, Prosecka E, Plencner M, Ocheretna L, et al. Non-woven PGA/PVA fibrous mesh as an appropriate scaffold for chondrocyte proliferation. Physiol Res. 2010;59:773-81.

184. Mukherjee DP, Smith DF, Rogers SH, Emmanual JE, Jadin KD, Hayes BK. Effect of 3D-microstructure of bioabsorbable PGA:TMC scaffolds on the growth of chondrogenic cells. J Biomed Mater Res B Appl Biomater. 2009;88B:92-102. doi:10.1002/jbm.b.31155.

185. Wang L, Seshareddy K, Weiss ML, Detamore MS. Effect of initial seeding density on human umbilical cord mesenchymal stromal cells for fibrocartilage tissue engineering. Tissue Eng Part A. 2009;15:1009-17. doi:10.1089/ten.tea.2008.0012.

186. Pati F, Adhikari B, Dhara S. Development of chitosantripolyphosphate non-woven fibrous scaffolds for tissue engineering application. J Mater Sci Mater Med. 2012;23: 1085-96. doi:10.1007/s10856-012-4559-9.

187. Wong CS, Nuhiji E, Sutti A, Keating G, Liu X, Kirkland M, et al. Enhanced cell growth using non-woven scaffolds of multilobal fibres. Text Res J. 2012;82:1371-81. doi:10.1177/ 0040517512439915.

188. Kasoju N, Bhonde RR, Bora U. Preparation and characterization of Antheraea assama silk fibroin based novel non-woven scaffold for tissue engineering applications. J Tissue Eng Regen Med. 2009;3:539-52. doi:10.1002/term.196.

189. Pasquinelli G, Orrico C, Foroni L, Bonafe F, Carboni M, Guarnieri $\mathrm{C}$, et al. Mesenchymal stem cell interaction with a non-woven hyaluronan-based scaffold suitable for tissue repair. J Anat. 2008;213:520-30. doi:10.1111/j.1469-7580.2008.00974.x.

190. Efe T, Theisen C, Fuchs-Winkelmann S, Stein T, Getgood A, Rominger MB, et al. Cell-free collagen type I matrix for repair of cartilage defects-clinical and magnetic resonance imaging results. Knee Surg Sports Traumatol Arthrosc. 2012;20:1911-8. doi:10.1007/s00167-011-1777-5.

191. Gavenis K, Schmidt-Rohlfing B, Andereya S, Mumme T, Schneider U, Mueller-Rath R. A cell-free collagen type I device for the treatment of focal cartilage defects. Artif Organs. 2010;34:79-83. doi:10.1111/j.1525-1594.2009.00776.x.

192. Gotterbarm T, Richter W, Jung M, Vilei SB, Mainil-Varlet P, Yamashita $\mathrm{T}$, et al. An in vivo study of a growth-factor enhanced, cell free, two-layered collagen-tricalcium phosphate in deep osteochondral defects. Biomaterials. 2006;27:3387-95. doi:10.1016/j.biomaterials.2006.01.041.

193. Yokoya S, Mochizuki Y, Nagata Y, Deie M, Ochi M. Tendonbone insertion repair and regeneration using polyglycolic acid sheet in the rabbit rotator cuff injury model. Am J Sports Med. 2008;36:1298-309. doi:10.1177/0363546508314416.

194. Funakoshi T, Majima T, Suenaga N, Iwasaki N, Yamane S, Minami A. Rotator cuff regeneration using chitin fabric as an acellular matrix. J Shoulder Elbow Surg. 2006;15:112-8. doi:10. 1016/j.jse.2005.05.012.

195. Yang Y, Ding F, Wu H, Hu W, Liu W, Liu H, et al. Development and evaluation of silk fibroin-based nerve grafts used for peripheral nerve regeneration. Biomaterials. 2007;28:5526-35. doi:10.1016/j.biomaterials.2007.09.001.

196. Aberg M, Ljungberg C, Edin E, Millqvist H, Nordh E, Theorin A, et al. Clinical evaluation of a resorbable wrap-around implant as an alternative to nerve repair: a prospective, assessor-blinded, randomised clinical study of sensory, motor and functional recovery after peripheral nerve repair. J Plast Reconstr Aesthet Surg. 2009;62:1503-9. doi:10.1016/j.bjps.2008.06.041.

197. Tian L, Prabhakaran MP, Ramakrishna S. Strategies for regeneration of components of nervous system: scaffolds, cells and biomolecules. Regen Biomater. 2015;2:31-45. doi:10.1093/rb/ rbu017.

198. Donoghoe N, Rosson GD, Dellon AL. Reconstruction of the human median nerve in the forearm with the Neurotube ${ }^{\mathrm{TM}}$ Microsurgery. 2007;27:595-600. doi:10.1002/micr.20408.

199. Navissano M, Malan F, Carnino R, Battiston B. Neurotubeo((R)) for facial nerve repair. Microsurgery. 2005;25: 268-71. doi:10.1002/micr.20128.

200. Waris E, Ashammakhi N, Lehtlmaki M, Tulamo R, Kellomaki $\mathrm{M}$, Tomala $\mathrm{P}$, et al. The use of biodegradable scaffold as an alternative to silicone implant arthroplasty for small joint reconstruction: an experimental study in minipigs. Biomaterials. 2008;29:683-91. doi:10.1016/j.biomaterials.2007.10.037.

201. Honkanen PB, Kellomaki M, Lehtimaki MY, Tormala P, Makela S, Lehto MU. Bioreconstructive joint scaffold implant arthroplasty in metacarpophalangeal joints: short-term results of a new treatment concept in rheumatoid arthritis patients. Tissue Eng. 2003;9:957-65. doi:10.1089/107632703322495600. 
202. Honkanen PB, Tiihonen R, Skytta ET, Ikavalko M, Lehto MUK, Konttinen YT. Bioreconstructive poly-L/D-lactide implant compared with swanson prosthesis in metacarpophalangeal joint arthroplasty in rheumatoid patients: a randomized clinical trial. J Hand Surg Eur Vol. 2010;35E:746-53. doi:10.1177/ 1753193410375777.

203. Tiihonen R, Honkanen PB, Belt EA, Ikavalko M, Skytta ET. The mean seven years' results of the use of poly-L/D-lactic acid (pldla) interposition implant and bone packing in revision metacarpophalangeal arthroplasty: a prospective cohort study. Scand J Surg. 2012;101:265-70.

204. Tiihonen RP, Skytta ET, Kaarela K, Ikavalko M, Belt EA. Reconstruction of the trapeziometacarpal joint in inflammatory joint disease using interposition of autologous tendon or poly-LD-lactic acid implants: a prospective clinical trial. J Plast Surg Hand Surg. 2012;46:113-9. doi:10.3109/2000656X.2012. 669202.

205. Torikai K, Ichikawa H, Hirakawa K, Matsumiya G, Kuratani T, Iwai $\mathrm{S}$, et al. A self-renewing, tissue-engineered vascular graft for arterial reconstruction. J Thorac Cardiovasc Surg. 2008;136:37-45. doi:10.1016/j.jtcvs.2007.06.039.

206. Iwai S, Sawa Y, Taketani S, Torikai K, Hirakawa K, Matsuda H. Novel tissue-engineered biodegradable material for reconstruction of vascular wall. Ann Thorac Surg. 2005;80:1821-8. doi:10. 1016/j.athoracsur.2005.03.139.

207. Iwai S, Sawa Y, Ichikawa H, Taketani S, Uchimura E, Chen GP, et al. Biodegradable polymer with collagen microsponge serves as a new bioengineered cardiovascular prosthesis. J Thorac
Cardiovasc Surg. 2004;128:472-9. doi:10.1016/j.jtcvs.2004.04. 013.

208. Urita Y, Komuro H, Chen G, Shinya M, Saihara R, Kaneko M. Evaluation of diaphragmatic hernia repair using PLGA meshcollagen sponge hybrid scaffold: an experimental study in a rat model. Pediatr Surg Int. 2008;24:1041-5. doi:10.1007/s00383008-2212-y.

209. Gomez G, Korkiakoski S, Gonzalez M, Lansmann S, Ella V, Salo T, et al. Effect of FGF and polylactide scaffolds on calvarial bone healing with growth factor on biodegradable polymer scaffolds. J Craniofac Surg. 2006;17:935-42.

210. Lansman S, Paakko P, Ryhanen J, Kellomaki M, Waris E, Tormala P, et al. Poly-L/D-lactide (PLDLA) 96/4 fibrous implants: histological evaluation in the subcutis of experimental design. J Craniofac Surg. 2006;17:1121-8.

211. Starritt NE, Kettle SAJ, Glasby MA. Sutureless repair of the facial nerve using biodegradable glass fabric. Laryngoscope. 2011;121:1614-9. doi:10.1002/lary.21868.

212. MacGillivray JD, Fealy S, Terry MA, Koh JL, Nixon AJ, Warren RF. Biomechanical evaluation of a rotator cuff defect model augmented with a bioresorbable scaffold in goats. J Shoulder Elbow Surg. 2006;15:639-44. doi:10.1016/j.jse. 2005.11.009.

213. Bini TB, Gao SJ, Xu XY, Wang S, Ramakrishna S, Leong KW. Peripheral nerve regeneration by microbraided poly(L-lactideco-glycolide) biodegradable polymer fibers. J Biomed Mater Res A. 2004;68A:286-95. doi:10.1002/jbm.a.20050. 